$$
\begin{aligned}
& \text { UNIVERSIDADE DE SÃO PAULO } \\
& \text { INSTITUTO DE GEOCIÊNCIAS }
\end{aligned}
$$

\title{
PROVENIÊNCIA SEDIMENTAR DO GRUPO GUARITAS, CAMBRIANO DA BACIA DO CAMAQUÃ (RS)
}

\author{
Jorge Emanuel dos Santos Nóbrega
}

Orientador: Prof. Dr. André Oliveira Sawakuchi

\section{DISSERTAÇÃO DE MESTRADO}

Programa de Pós-Graduação em Geoquímica e Geotectônica

SÃO PAULO 
"O meu livro era o Brasil, não o mapa do Brasil, mas a terra do Brasil, onde eu piso, onde eu sinto, onde eu percorro"

Heitor Villa-Lobos

"Dois problemas se misturam: a verdade do universo e a prestação que vai vencer."

Raul Seixas 


\section{Índice}

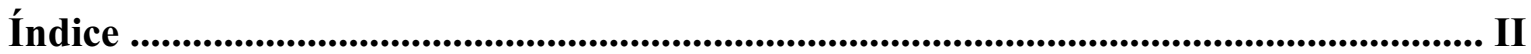

Índice de Figuras .......................................................................................................... III

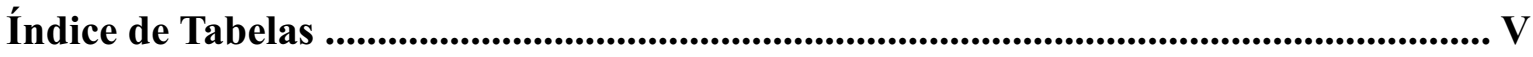

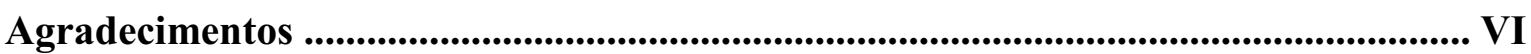

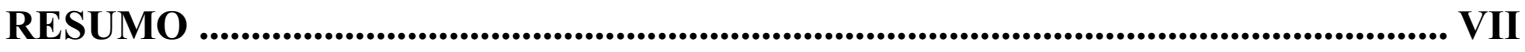

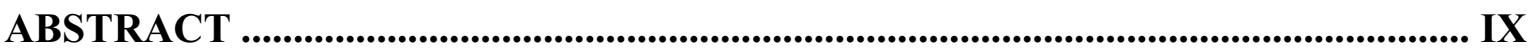

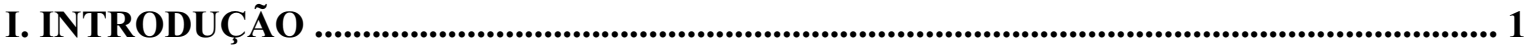

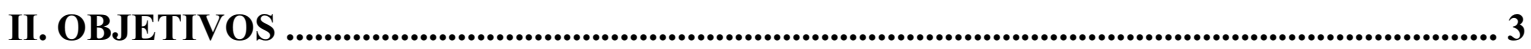

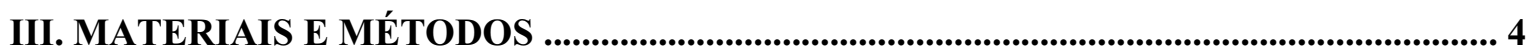

III.1.Descrição de fácies sedimentares e coleta de amostras .................................................. 4

III.2.Petrografia de seções delgadas ............................................................................................... 4

III.3.Análise de minerais pesados ....................................................................................... 5

III.3.1.SEPARAÇÃO DE MINERAIS PESADOS E CONFECÇÃO DE LÂMINAS DE GR AOS

III.3.2.QUANTIFICAÇÃO DA ASSEMBLÉIA DE MINERAIS PESADOS E DETERMINAÇÃO DE ÍNDICES MINERALÓGICOS (ZTR, ZRi, ZTi E ATi) .................... 5

III.4.Análises de sensibilidade LOE ..............................................................................................6 6

III.4.1.PREPARAÇÃO DE AMOSTRAS DE GRÃOS DE QUARTZO .................. 6

III.4.2.MEDIDAS LOE EM GRÃOS INDIVIDUAIS ............................................ 6

III.5.Análise estatística descritiva de índices de minerais pesados e medidas LOE ..... 8

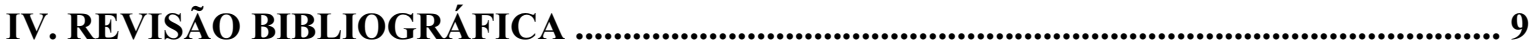

IV.1.Geologia da Área de Estudo ......................................................................................... 9

IV.1.1.CONTEXTO TECTONO-ESTRATIGRÁFICO _........................................ 9

IV.1.2.O GRUPO GUARITAS ............................................................. 10

IV.2.Análise de proveniência sedimentar .................................................................... 13

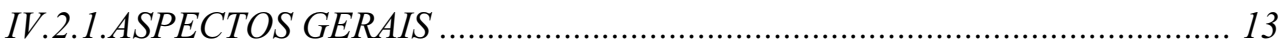

IV.2.2.ÍNDICES BASEADOS EM MINERAIS PESADOS …............................... 14

IV.2.3.LUMINESCÊNCIA DO QUARTZO ………............................................ 15

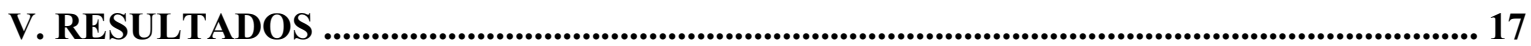

V.1.Fácies Sedimentares ................................................................................................... 17

V.2.Petrografia de seções delgadas ............................................................................................ 22

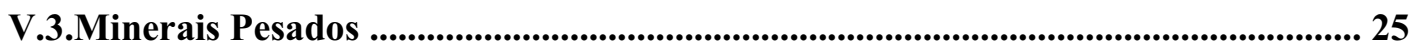

V.3.1.DESCRIÇÃO DA ASSEMBLÉIA DE MINERAIS PESADOS .................... 25

V.3.2.ÍNDICES DE MINERAIS PESADOS (ZTR, ZTi, ZRi E ATi) ...................... 26

V.4.Sensibilidade LOE do quartzo ................................................................................................ 31

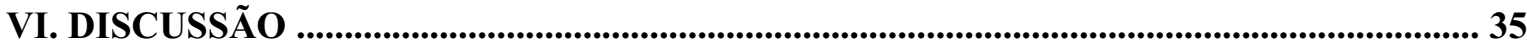

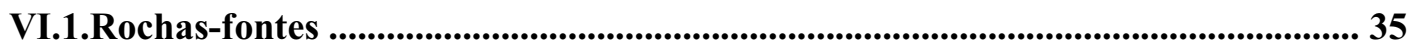

VI.2.Retrabalhamento e aporte sedimentar .............................................................................. 37

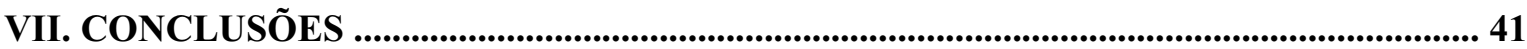

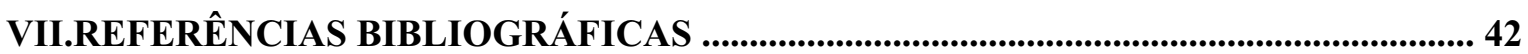

ANEXO - DADOS DE MINERAIS PESADOS .................................................................................. 48 


\section{Índice de Figuras}

Figura 1: Divisão da curva LOE em três intervalos, informalmente chamados de rápido (1-10), médio (10-30) e lento (30-50).

Figura 2: Mapa geológico esquemático da Bacia do Camaquã e áreas vizinhas (modificado de Almeida 2005).

Figura 3: Mapa geológico do Grupo Guaritas (modificado de Almeida 2005). 12

Figura 4: Carta estratigráfica esquemática do Grupo Guaritas (adaptada de Almeida et al. 2009). 13

Figura 5: Mapas de pontos. A. Mapa de pontos dos afloramentos visitados. B. Mapa de pontos com análise de minerais pesados. C. Mapa de pontos com análise da sensibilidade LOE do quartzo.

Figura 6: Fotos de fácies. A e B: Conglomerado a arenito conglomerático (fácies ACc) das formações Guarda Velha e Varzinha, respectivamente. C a F: Arenito fino com estratificação plano-paralela e laminação heterolítica (fácies AFph) da Formação Varzinha. Notar gretas de contração nas fotos E e F. 20

Figura 7: Fotos de fácies. A a E: Formação Pedra Pintada; F: Formação Serra do Apertado. A e B: Arenito fino com estratificação cruzada acanalada em séries decimétricas a métricas (fácies $\mathrm{AFc}$ ). $\mathrm{C}$ : Arenito fino com estratificação plano-paralela em séries métricas (AFpg). D: Superfície de deflação associada a fácies AFp (Arenito fino com estratificação plano-paralela em séries decimétricas). E: Arenito com grânulos e seixos e estratificação plano-paralela (AGp). F: Arenito conglomerático e conglomerado com estratificação cruzada acanalada em séries decimétricas a métricas (ACc).

Figura 8: Fotos de seções delgadas. A e B: fácies ACc da Formação Serra do Apertado. C e D: fácies AFph da Formação Varzinha. E: fácies AGp da Formação Pedra Pintada. Notar grânulos de andesito e granito à direita nas fotos $\mathrm{A}$ e $\mathrm{C}$, respectivamente.

Figura 9: Fotos de seções delgadas. A: fácies AFpg na Fm. Pedra Pintada. Notar imbricamento dos grãos. B: laminação bimodal (pin stripe) presente na fácies AFc da Fm. Pedra Pintada. C: fácies AGp na Fm. Pedra Pintada. D e E: fácies ACc com fragmentos líticos (granito, andesito, filito) na Fm. Serra do Apertado.

Figura 10: Minerais pesados identificados nas unidades do Grupo Guaritas: Zircão (A, B, C, D); Turmalina $(\mathrm{E}, \mathrm{F}, \mathrm{G}, \mathrm{H})$; Apatita $(\mathrm{I}, \mathrm{J}, \mathrm{K}, \mathrm{L})$; Granada $(\mathrm{M}, \mathrm{N})$; Rutilo $(\mathrm{O}, \mathrm{P})$ (nicóis paralelos em: A, B, C, E, F, H, I, J, K, $\mathrm{M}, \mathrm{N}, \mathrm{O}, \mathrm{P}$; nicóis cruzados em $\mathrm{D}, \mathrm{G}, \mathrm{L})$.

Figura 11: Minerais pesados identificados nas unidades do Grupo Guaritas: Anatásio (A, B); Titanita (C, D); Epidoto (E, F); Sillimanita (G, H); Monazita (I); Estaurolita (J, K); Hornblenda (L) (nicóis paralelos em: A, B, C, D, E, G, I, J, L; nicóis cruzados em F, H, K).

Figura 12: Valores do índice ATi para as amostras das unidades do Grupo Guaritas. Amostras com baixo índice ATi são destacadas.

Figura 13: Boxplot dos índices ZTi, ZRi, ATi e ZTR, separados por unidade estratigráfica. O boxplot é constituído de uma caixa limitada pelos $1^{\circ}$ e $3^{\circ}$ quartis (Q1 e Q3) e dividida pela mediana, possui duas retas, denominadas bigodes, cujos comprimentos respondem à Q1-1,5(Q3-Q1) ou valor mínimo e Q3+1,5(Q3-Q1) ou valor máximo. Os valores fora desse intervalo são denominados anômalos (outliers) e representados por asteriscos.

Figura 14: Boxplot dos índices ZTi, ZRi, ATi e ZTR, separados por sistema deposicional. 30

Figura 15: Gráficos boxplot para as medidas de sensibilidade LOE total (Integral (1-50)), com e sem valores anômalos (outliers), separadas por unidade estratigráfica. Sensibilidade LOE em contagens de fótons. 32 
Figura 16: Gŕaficos Boxplot para as porcentagens dos componentes (rápido, médio e lento) de sensibilidade LOE, separados por unidade estratigráfica.

Figura 17: Gŕaficos Boxplot para as porcentagens dos componentes (rápido, médio e lento) de sensibilidade LOE, separados por sistema deposicional.

Figura 18: Gráficos ternários das porcentagens dos componentes rápido $(\mathrm{R})$, médio (M) e lento (L), separados por unidades estratigráficas.

Figura 19: Gráficos ternários das porcentagens dos componentes LOE (rápido, médio e lento) medidos por Sawakuchi et al. (2010) em sedimentos fluviais e costeiros (dunares e praiais), os quais apresentam graus de retrabalhamento baixo (monocíclico) e elevado (policíclico), respectivamente.

Figura 20: Modelo esquemático das interações entre os sistemas deposicionais do Grupo Guaritas. Setas maiores correspondem a aportes maiores. 


\section{$\underline{\text { Índice de Tabelas }}$}

Tabela 1: Seqüência de procedimentos aplicados com o leitor Risø TL/OSL DA-15 para avaliar a sensibilidade LOE de grãos individuais de quartzo. A taxa de aquecimento foi de $5^{\circ} \mathrm{C} / \mathrm{s}$.

Tabela 2: Fácies sedimentares das formações Varzinha, Pedra Pintada, Pedra da Arara e Serra do Apertado, amostradas para petrografia de seções delgadas e análises de minerais pesados e de luminescência do quartzo. As letras maiúsculas das siglas das fácies referem-se à características granulométricas e as letras minúsculas às estruturas sedimentares diagnósticas.

Tabela 3: Descrição e freqüência de ocorrência dos minerais pesados observados nas amostras do Grupo Guaritas.

Tabela 4: Proporções médias, máximas e mínimas dos minerais pesados encontrados nas amostras das formações Guarda Velha, Varzinha, Pedra Pintada e Serra do Apertado.

Tabela 5: Estatísticas descritivas dos índices ZTR, ZTi, ZRi e ATi, separados por unidades estratigráficas._29

Tabela 6: Estatísticas descritivas dos índices ZTR, ZTi, ZRi e ATi, categorizados por sistema deposicional.29

Tabela 7: Estatísticas descritivas da intensidade LOE total (Integral (1-50)) e dos componentes rápido, médio e lento, categorizados por unidades estratigráficas. A intensidade LOE total é representada em contagens de fótons.

Tabela 8: Estatísticas descritivas da intensidade LOE total e das porcentagens dos componentes rápido, médio e lento, categorizadas por sistema deposicional. 


\section{$\underline{\text { Agradecimentos }}$}

Em primeiro lugar, mas não mais importante, eu gostaria de agradecer a todas as pessoas não lembradas que direta ou indiretamente, ajudaram no desenvolvimento e conclusão deste trabalho.

Em especial, ao meu orientador, Prof. Dr. André Oliveira Sawakuchi, pelo auxílio financeiro no início deste trabalho, por sempre ter tempo pra discutir o que quer que fosse, por saber a hora certa de cobrar avanços e resultados, por me ensinar a adaptar o modelo aos dados e não os dados ao modelo, e pela amizade.

Ao Dr. Michael W. Blair, do Los Alamos National Laboratory (Earth and Enviromental Sciences Division), pela ajuda nas análises de luminescência.

Ao Prof. Dr. Renato Paes de Almeida, pelos campos, pelas referências, pelas discussões e por tirar minhas dúvidas por mais básicas que fossem; ao Prof. Dr. Paulo César Fonseca Giannini e Prof. Dra. Ana Maria Góes, por sempre estarem prontos a tirar minhas dúvidas com os minerais pesados e com processos e produtos.

Ao amigo André Marconato (Kodornna) por tornar esse mais trabalho mais divertido, por todas as discussões geológicas ou não, pelos campos, etc.

Pela ajuda nas etapas de campo aos mestres Felipe Figueiredo (Banheirão) e Carlos Guedes (Sfincter) e às graduandas Maria Carolina Catunda (Obelix) e Letícia Guimarães (Beiça).

Aos colegas da pós: Felipe Ochoa (Orso), Dr. Daniel Nascimento Jr. (Pegmatito), Brenda Rocha (Kups), Ana Paula Tanaka (Treme), Milene Fornari, Vinícius Ribau (Rebita), Maurício Guerreiro (Borboleta), Cléber Calça, Thaís (Tchitcho) e Roberta (Pisa) por me ajudarem nas mais diversas etapas.

Aos amigos Thomas Garcia e Rodrigo Bunevich, por dividirmos o mesmo teto.

Tenho também de agradecer aos funcionários do LabSed e LabPetro, da secretaria, da biblioteca e da gráfica, pois sem eles este trabalho não entraria no papel.

Aos meus pais, Francisco e Marízia, por sempre me apoiarem em minhas decisões.

À Laís, amor da minha vida, por me aguentar, me incentivar e acreditar em mim.

Tenho de agradecer também à FAPESP pelos Projetos de Pesquisa (06/50655-0, 07/54889-8 e 09/53362-1) e ao CNPq pela bolsa de estudos concedida.

E por último, mas não menos importante, a todos aqueles que embora não tenham contribuído de alguma forma para este trabalho, contribuíram nas 'horas felizes'. 


\section{RESUMO}

O Grupo Guaritas (Eocambriano da Bacia do Camaquã, RS) é formado por rochas siliciclásticas, predominantemente arenosas e conglomeráticas, interpretadas como de origem aluvial e eólica. Esta unidade estratigráfica pode apresentar mais de $1500 \mathrm{~m}$ de espessura de sedimentos e abrange as formações Guarda Velha, Pedra das Torrinhas, Varzinha, Pedra Pintada e Serra do Apertado. O Grupo Guaritas relaciona-se a importantes eventos geológicos do sul do Brasil, pois registra o encerramento da sedimentação em bacia extensional do tipo rifte (Bacia do Camaquã) durante o Cambriano, a qual se desenvolveu em área que seria posteriormente recoberta por ampla bacia intracratônica (a Bacia do Paraná), a partir do Ordoviciano.

Para contribuir com novas informações sobre a proveniência das unidades eopaleozóicas brasileiras, as rochas arenosas do Grupo Guaritas foram submetidas à análise de minerais pesados, petrografia de lâminas delgadas e luminescência opticamente estimulada (LOE). As análises de minerais pesados foram realizadas na fração areia muito fina de 44 amostras coletadas em afloramentos. Essas análises abrangeram a identificação e quantificação da assembléia de minerais pesados transparentes não-micáceos, além da $\begin{array}{lllll}\text { determinação dos índices } & \text { ZTR } & \text { (zircão+turmalina+rutilo), } & \text { ATi }\end{array}$ (apatita/(apatita+turmalina)), ZTi (zircão/(turmalina+zircão)) e ZRi (zircão/(rutilo+zircão). As seções delgadas foram utilizadas para descrever os componentes deposicionais e diagenéticos e para classificar os arenitos estudados. Quatro amostras selecionadas foram submetidas ainda à análise da sensibilidade LOE de grãos individuais de quartzo. A sensibilidade LOE foi calculada utilizando a integral da curva LOE assim como de seus componentes, chamados informalmente de rápido, médio e lento. A sensibilidade LOE foi usada para avaliação de grau de retrabalhamento sedimentar.

As amostras estudadas foram classificadas como arcóseos, subarcóseos e sublitoarenitos. Os minerais pesados identificados e suas porcentagens médias foram: zircão $(36 \%)$, turmalina $(13 \%)$, rutilo $(3 \%)$, apatita $(23 \%)$, granada $(16 \%)$, anatásio $(7 \%)$, titanita $(1 \%)$, sillimanita $(1 \%)$, monazita $(<1 \%)$, epidoto $(<1 \%)$, hornblenda $(<1 \%)$, estaurolita $(<1 \%)$ e cianita $(<1 \%)$. Esses minerais pesados foram descritos em todas as 
unidades estudadas do Grupo Guaritas. Os valores médios do índice ZTR variam de 20 (Fm. Serra do Apertado) a 40 (Fm. Pedra Pintada) enquanto que o índice ZTi apresenta valores médios entre 62 (Fm. Guarda Velha) e 73 (Fm. Pedra Pintada). Os valores médios dos índices ZRi e ATi variam de 81 (Fm. Guarda Velha) a 90 (Fm. Varzinha) e de 79 (Fm. Guarda Velha) a 83 (Fm. Serra do Apertado), respectivamente. As médias da sensibilidade LOE total do quartzo apresentaram valores médios maiores para as unidades inferiores $($ Fm. Guarda Velha $=3295$ contagens e Fm. Varzinha $=3655$ contagens $)$ em relação às superiores $($ Fm. Pedra Pintada $=2271$ contagens e Fm. Serra do Apertado $=2457$ contagens). As médias dos componentes LOE rápido (15-19\%), médio (37-38\%) e lento (43-46\%) não apresentam diferenças marcantes entre as unidades.

A assembléia de minerais pesados dominada por zircão, apatita e turmalina sugere que os sedimentos arenosos do Grupo Guaritas são derivados principalmente de rochas ígneas ácidas (granitos neoproterozóicos). A pequena variação do índice ZRi aponta manutenção da configuração litológica da área-fonte durante a deposição das unidades estudadas. A abundância de feldspatos, fragmentos líticos e, principalmente, de apatita indica deposição em ambiente árido e/ou soterramento rápido. Isto é coerente com a sensibilidade LOE do quartzo, que é relativamente reduzida, indicando baixo grau de retrabalhamento sedimentar para as areias do Grupo Guaritas. A sensibilidade LOE mais elevada das areias da Formação Guarda Velha representaria maior contribuição de sedimentos distais mais retrabalhados.A sensibilidade LOE do quartzo permite avaliar o grau de retrabalhamento de sedimentos antigos (Cambriano), já que até então este método tinha sido aplicado somente à sedimentos quaternários.

Palavras-chave: Grupo Guaritas, Arenitos, Cambrianos, Minerais Pesados, Luminescência Opticamente Estimulada, Proveniência 


\section{ABSTRACT \\ Sedimentary Provenance of the Guaritas Group, Cambrian from the Camaquã Basin, Southern Brazil}

The Guaritas Group (Eocambrian of the Camaquã Basin, southern Brazil) is mainly composed of fine to coarse-gravelly sandstones, interpreted as a record of fluvial and aeolian depositional systems. This stratigraphic unity may present more than $1500 \mathrm{~m}$ thick of sediments, comprising the Guarda Velha, Pedra das Torrinhas, Varzinha, Pedra Pintada and Serra do Apertado formations. The Guaritas Group relates to important geological events occurred in southern Brazil during the Eopaleozoic. Its deposition marks the final episode of sedimentary filling of an extensional rift basin (Camaquã Basin) during the Cambrian, in an area after covered by a huge intracratonic basin (Paraná Basin) during the Ordovician.

To contribute with new information about the provenance of Eopalaezoic Brazilian sediments, the sandy rocks of the Guaritas Group were analyzed through heavy minerals, thin section petrography and luminescence methods. Heavy minerals analyses were carried out in the very fine sand fraction of 44 rock samples collected from outcrops. These analyses included the identification and quantification of the transparent non-micaceous heavy minerals as well as the determination of the ZTR (zircon+tourmaline+rutile), ATi (apatite/(apatite+tourmaline)), ZTi (zircon/(tourmaline+zircon)) and ZRi (zircon/(rutile+zircon) indices. Thin section petrography was used to describe depositional and diagenetic components and classify the studied sandstones. Further, four samples were selected for measurements of optically stimulated luminescence (OSL) sensitivity in quartz single-grains. The OSL sensitivity was calculated using the total OSL curve as well as specific components, informally named fast, medium and slow. The OSL sensitivity of quartz has been used as a proxy for sedimentary reworking.

The studied sandstones were classified as arkoses, subarkoses and sublitharenites. The identified heavy minerals and their mean percentages were: zircon $(36 \%)$, tourmaline $(13 \%)$, rutile $(3 \%)$, apatite $(23 \%)$, garnet $(16 \%)$, anatase $(7 \%)$, titanite $(1 \%)$, sillimanite $(1 \%)$, monazite $(<1 \%)$, epidote $(<1 \%)$, hornblende $(<1 \%)$, staurolite $(<1 \%)$ and kyanite 
$(<1 \%)$. These heavy minerals were described in all studied units of the Guaritas Group. The mean values of the ZTR indice varied from 20 (Serra do Apertado Fm.) to 40 (Pedra Pintada Fm.) while the ZTi indice presented mean values between 62 (Guarda Velha Fm.) and 73 (Pedra Pintada Fm.). The mean values of the ZRi and ATi indices ranged from 81 (Guarda Velha Fm.) to 90 (Varzinha Fm.) and from 79 (Guarda Velha Fm.) to 83 (Serra do Apertado Fm.), respectively. The total OSL sensitivity of quartz demonstrated higher mean values for the bottom units (Guarda Velha Fm. $=3295$ counts; Varzinha Fm. $=3655$ counts) than for the upper units (Pedra Pintada Fm. $=2271$ counts, and Serra do Apertado Fm. $=2457$ counts). The means of the fast OSL component (15-19\%), medium (37-38\%) and slow (43-46\%) did not differ markedly among the units.

The heavy minerals assemblage dominated by zircon, tourmaline and apatite suggests that the sandy sediments of the Guaritas Group are mainly derived from acid igneous rocks (neoproterozoic granites). The low range of variation of the ZRi indice points out the maintenance of similar primary source rocks during the deposition of the Guaritas sediments. The abundance of unstable grains such as feldspars, lithic fragments and apatite indicates deposition under arid climate and/or high rate of sediment accumulation. The OSL sensitivity of quartz grains is relatively low, suggesting sands with low degree of reworking. This is compatible with the high content of unstable sand grains (apatite, feldspar and lithic fragments) and elevated rate of sediment accumulation. The greater proportion of grains with higher OSL sensitivity in the Guarda Velha Formation represents an increased contribution of sediments from distal more reworked sources.The OSL sensitivity of quartz allows evaluate the degree of reworking of older sediments (Cambrian), since this method had been applied only to Quaternary sediments.

Keywords: Guaritas Group, Sandstones, Cambrian, Heavy Minerals, Optically Stimulated Luminescence, Provenance 


\section{INTRODUÇÃO}

O Grupo Guaritas, Eocambriano da Bacia do Camaquã (Almeida et al. 2010), é formado por rochas siliciclásticas, predominantemente arenosas e conglomeráticas, interpretadas como de origem aluvial e eólica (Robertson 1966, Lavina et al. 1985, Paim 1994, Almeida 2005). Esta unidade estratigráfica contempla mais de $1500 \mathrm{~m}$ de espessura de sedimentos e abrange as formações Guarda Velha, Pedra das Torrinhas, Varzinha, Pedra Pintada e Serra do Apertado (Almeida et al. 2009). Assim, o Grupo Guaritas relaciona-se a importantes eventos geológicos do sul do Brasil, pois registra o encerramento da sedimentação em bacia extensional do tipo rifte (Bacia do Camaquã) durante o Cambriano (Almeida et al. 2010), a qual desenvolveu-se em área que seria posteriormente recoberta por ampla bacia intracratônica (a Bacia do Paraná), a partir do Ordoviciano.

Sistemas deposicionais eólicos e aluviais, por serem responsáveis por aquíferos de grandes dimensões e por importantes reservatórios de hidrocarbonetos, têm sido estudados principalmente sob o ponto de vista da arquitetura deposicional (Marconato et al. 2009, Almeida et al. 2009, Santos 2010). Modelos de fácies bastante detalhados foram desenvolvidos para os principais tipos de sistemas deposicionais fluviais (e.g. Collinson 1996, Miall 1996) e eólicos (e.g. Brookfield 1992, Kocurek 1996). Porém, as particularidades e os tipos de interações entre os dois sistemas são menos documentados (e.g. Langford 1989, Langford \& Chan 1989), especialmente no que se refere ao transporte de sedimentos.

Em estudos recentes sobre o Grupo Guaritas (Marconato et al. 2009, Almeida et al. 2009) têm se revelado a presença de elementos de interação eólico-fluvial ainda pouco registrados na bibliografia. Tais elementos incluem fácies de inundação de áreas de interdunas por sistemas fluviais adjacentes, semelhantes às descritas por Stanistreet \& Stollhofen (2002) em depósitos recentes no deserto da Namíbia, e o desenvolvimento de lençóis de areia e pequenas dunas eólicas associados a sistemas fluviais efêmeros e regiões distais de leques aluviais.

Para contribuir com novas informações sobre a interação entre sistemas fluvial e eólico e a paleogeografia do Grupo Guaritas, buscou-se abordagem baseada na análise de proveniência sedimentar. Para tanto, adotou-se a análise de minerais pesados, como 
ferramenta principal, aliada à classificação composicional dos arenitos em estudo. Esse tipo de análise de proveniência é escasso para unidades sedimentares paleozóicas brasileiras, como é o caso do Grupo Guaritas. Além disso, as unidades do Grupo Guaritas (formações Guarda Velha, Varzinha, Pedra Pintada e Serra do Apertado) serviram de base para testar em rochas paleozóicas a sensibilidade LOE (luminescência opticamente estimulada) do quartzo como indicador de proveniência sedimentar, já que os resultados de Pietsch et al. (2008) e Sawakuchi et al. (2010) foram obtidos em sedimentos quaternários.

Os métodos empregados visaram identificar possíveis rochas-fonte para as unidades; diferenciá-las de acordo com suas áreas-fontes; avaliar o grau de retrabalhamento sedimentar; compreender suas interações, ou seja, se serviram de fonte umas as outras; e buscar informações sobre o clima. 


\section{OBJETIVOS}

Os objetivos deste estudo envolvem questões ligadas às áreas fontes, sistemas deposicionais e sua relação com a estratigrafia das unidades constituintes do Grupo Guaritas. Estes objetivos são expressos pelas seguintes questões:

- Quais foram as rochas fontes dos sedimentos para os sistemas deposicionais fluvial e eólico, atuantes durante a sedimentação do Grupo Guaritas?

- Houve mudanças das rochas fontes dos sedimentos ao longo do período de desenvolvimento destes sistemas deposicionais?

- Como os sistemas deposicionais fluvial e eólico interagiram em termos de trocas de sedimentos?

- A sensibilidade LOE do quartzo apresenta resultados coerentes de grau de retrabalhamento sedimentar para rochas paleozóicas assim como apresenta para sedimentos recentes?

Para tentar responder estas questões foram executadas as seguintes tarefas:

- Descrição de fácies sedimentares e coleta de amostras para estudos laboratoriais;

- Petrografia de seções delgadas para descrição de componentes deposicionais e diagenéticos dos arenitos;

- Análise de minerais pesados dos arenitos;

- Medidas de sensibilidade LOE de grãos de quartzo dos arenitos;

- Análise estatística dos dados obtidos. 


\section{MATERIAIS E MÉTODOS}

\section{III.1.Descrição de fácies sedimentares e coleta de amostras}

Segundo Miall (2000), a análise de fácies compreende o estudo e a interpretação de texturas, estruturas sedimentares, fósseis e associações litológicas de rochas sedimentares em escala de afloramentos e testemunhos de sondagem. "A interpretação genética de uma fácies isolada, antes da descrição de fácies vizinhas de mesmo contexto sedimentar, tende a ser muito mais ambígua que a interpretação das fácies já descritas como um conjunto coerente" (Anderton 1985). Assim, a análise de fácies deve ser feita de modo integrado, com sucessivas reinterpretações das fácies individuais até a elaboração de um modelo coerente e desprovido de contradições internas. Estes princípios nortearam a análise de fácies em afloramentos das unidades estratigráficas do Grupo Guaritas.

As fácies foram descritas em sucessões estratigráficas verticais compostas, traçadas com auxílio de bússola e trena. Os litotipos arenosos de agrupamentos de fácies e sucessões sedimentares individualizadas por superfícies estratigráficas foram amostradas para caracterização quantitativa da assembléia de minerais pesados e da sensibilidade LOE do quartzo e qualitativa dos seus componentes petrográficos (arcabouço, matriz e cimento).

As unidades estudadas contam com arcabouço estratigráfico definido em estudos anteriores (Paim et al. 1995, Paim \& Scherer 2003, Almeida 2005, Almeida et al. 2009). Assim, o levantamento de seções estratigráficas por meio da descrição de afloramentos visa o refinamento de modelos previamente definidos e melhor contextualização das amostras coletadas. Estas foram coletadas com o auxilio de ponteiro e marreta, sendo que algumas foram coletadas com o auxílio de uma perfuratriz, movida por motor a explosão e broca com alcance máximo de $15 \mathrm{~cm}$, permitindo a obtenção de amostras com menor grau de intemperismo.

\section{III.2.Petrografia de seções delgadas}

A análise petrográfica das seções delgadas tiveram como objetivo a classificação das rochas arenosas amostradas. Para isto, utilizou-se a classificação proposta por Folk (1968), que enfatiza os componentes do arcabouço. A caracterização petrográfica do arcabouço, 
matriz e cimento das rochas arenosas possibilita ainda o refinamento da descrição das fácies, assim como também fornece indícios de suas rochas fontes e parâmetros de correlação entre unidades ou horizontes estratigráficos.

\section{III.3.Análise de minerais pesados}

III.3.1.SEPARAÇÃO DE MINERAIS PESADOS E CONFECÇÃO DE LÂMINAS DE GRÃOS

No total, 44 amostras de arenitos e arenitos conglomeráticos das formações Guarda Velha, Varzinha, Pedra Pintada e Serra do Apertado foram fragmentadas e desagregadas manualmente em almofariz, com uso de pilão de borracha. Posteriormente, as amostras foram elutriadas, para eliminação das frações silte e argila, e peneiradas para aquisição da fração granulométrica entre 0,063 e 0,125mm (areia muito fina). Esta fração foi submetida a ensaio de flutuação-afundamento em líquido denso (bromofórmio, $\mathrm{CHBr}_{3}, \rho=2,85 \mathrm{~g} / \mathrm{cm}^{3}$ ), segundo os procedimentos descritos por Parfernoff et al. (1970), para separação entre as porções de minerais leves e pesados. Lâminas de grãos de minerais pesados foram confeccionadas com bálsamo do Canadá.

\section{III.3.2.QUANTIFICAÇÃO DA ASSEMBLÉIA DE MINERAIS PESADOS E DETERMINAÇÃO} DE ÍNDICES MINERALÓGICOS (ZTR, ZRi, ZTi E ATi)

Os grãos de minerais pesados transparentes e não-micáceos foram identificados e quantificados ao microscópio petrográfico de luz transmitida. A contagem de grãos de minerais pesados seguiu o procedimento de "ribbon counting", descrito por Galehouse (1971) e Mange \& Maurer (1992). Neste método, realiza-se a contagem de pelo menos 100 grãos de minerais pesados transparentes e não-micáceos ao longo de faixa selecionada de modo aleatório na lâmina delgada. De acordo com Van Andel (1950), as diferenças entre as proporções dos minerais mais abundantes quando contagens de 100 e 600 grãos de minerais são comparadas, são menores que 5\%.

A análise de minerais pesados também envolveu o cálculo do índice ZTR (Hubert 1962) e dos índices baseado em pares de minerais ZRi, ZTi e ATi (Morton \& Hallsworth 1994; Guedes et al. 2011). A determinação de cada índice baseado em pares minerais foi feita por meio da contagem de 100 grãos dos minerais que compõem o respectivo índice. $\mathrm{O}$ índice ZTR e os índices baseados em pares de minerais pesados (ABi) foram calculados respectivamente por:

$$
\text { ZTR }=100 \times \text { [(Zircão + Turmalina }+ \text { Rutilo }) / \text { Assembléia Mineral Total }]
$$




$$
\mathrm{ABi}=100 \times[\mathrm{A} /(\mathrm{A}+\mathrm{B})]
$$

\section{III.4.Análises de sensibilidade LOE}

\section{III.4.1.PREPARAÇÃO DE AMOSTRAS DE GRÃOS DE QUARTZO}

Estas análises têm por objetivo a obtenção de medidas de sensibilidade LOE de amostras de grãos de quartzo provenientes das unidades do Grupo Guaritas. Estas amostras foram previamente caracterizadas por análises petrográficas e de minerais pesados. Características derivadas da análise da forma das curvas LOE foram testadas como assinatura da origem dos grãos de quartzo. A realização de análises LOE em grãos únicos de quartzo (single grain analysis) permite avaliar o retrabalhamento sedimentar dos grãos individuais, o que possibilitaria diferenciar unidades com diferentes graus de retrabalhamento.

Para cada unidade estudada, foi selecionada uma amostra de rocha, totalizando quatro amostras. Estas amostras foram desagregadas e submetidas ao peneiramento úmido para a obtenção da fração entre 180-250 $\mu \mathrm{m}$. Foi então realizada a separação dos minerais pesados com $\mathrm{CHBr}_{3}\left(\rho=2.85 \mathrm{~g} / \mathrm{cm}^{3}\right)$ e tratamento com $\mathrm{HCl}(10 \%)$ e $\mathrm{HF}(48-51 \%$, por $2 \mathrm{~h})$ para a eliminação de carbonatos e feldspatos, respectivamente. Após os tratamentos químicos, que podem reduzir o tamanho dos grãos de quartzo, as amostras foram novamente peneiradas para separar a fração entre 180-250 $\mu \mathrm{m}$. Antes das análises LOE, o quartzo obtido foi fotoesvaziado sob a luz do Sol por período de 3 a 5 horas. Grãos individuais de quartzo foram colocados em discos de alumínio contendo uma grade de 10 x 10 covas cilíndricas, de 300 $\mu \mathrm{m}$ de diâmetro, que têm capacidade para 1 a 3 grãos. Para cada amostra, foram preparados dois ou três discos de grãos individuais de quartzo. A pureza do quartzo obtido foi verificada com a ajuda da lupa binocular. Apesar do ataque por HF, alguns grãos de feldspato resistem ao tratamento. Assim, os grãos de cada cova foram observados sob a lupa e somente as covas com grãos de quartzo foram utilizadas nas análises. Covas vazias e covas com grãos de outros minerais (feldspatos e micas) foram excluídos da análise dos dados. Este processo garantiu que todas as curvas LOE analisadas fossem provenientes de grãos individuais de quartzo. Desse modo, no mínimo 150 grãos de quartzo por amostra foram analisados.

\section{III.4.2.MEDIDAS LOE EM GRÃOS INDIVIDUAIS}

As medidas LOE de grãos individuais de quartzo foram realizadas em um leitor Risø TL/OSL DA-15 no Los Alamos National Laboratory (Los Alamos, EUA). O leitor é equipado com um laser verde $(532 \mathrm{~nm})$ para estimulação óptica dos grãos, um tubo fotomultiplicador bialkali (Thorn EMI 9635QB), filtros Hoya U-340 (290-370 nm) para restringir os comprimentos de onda detectados e uma fonte beta $\left({ }^{90} \mathrm{Sr} /{ }^{90} \mathrm{Y}\right)$ acoplada com taxa de dose de 
$0.0139 \mathrm{~Gy} / \mathrm{s}$. As medidas LOE foram realizadas sob estímulo com intensidade crescente (Linear Modulation, LM) Os grãos de quartzo foram submetidos à seqüência de medidas apresentada na Tabela 1 .

Tabela 1: Seqüência de procedimentos aplicados com o leitor Risø TL/OSL DA-15 para avaliar a sensibilidade LOE de grãos individuais de quartzo. A taxa de aquecimento foi de $5^{\circ} \mathrm{C} / \mathrm{s}$.

\begin{tabular}{|c|l|}
\hline Passo & Tratamento \\
\hline 1 & Esvaziamemto a $125^{\circ} \mathrm{C}$ por 1s com laser verde (intensidade em 90\%) \\
\hline 2 & Aplicação de dose de radiação beta de $100 \mathrm{~Gy}$ \\
\hline 3 & $\begin{array}{l}\text { Medição da LM-LOE por } 10 \mathrm{~s} \text { a } 125^{\circ} \mathrm{C} \text { com laser verde (potência de 0 a } \\
100 \%)\end{array}$ \\
\hline
\end{tabular}

As curvas LM-LOE foram adquiridas em 50 canais e possuem $0.2 \mathrm{~s}$ de resolução (tempo/ponto medido). A sensibilidade LOE de cada grão de quartzo foi obtida pela integral da curva LM-LOE total ou parcial. A divisão das curvas LM-LOE em três intervalos (canais 1-10, 10-30 e 30-50) permitiu avaliar a sensibilidade LOE de componentes distintos, informalmente chamados de rápido, médio e lento (Figura 1). Parâmetros como: integral (150), que representa a área sob a curva LOE; \%rápido, \%médio e \%lento, que representam a porcentagem de cada trecho da curva LOE; rápido (contagens/canal), médio

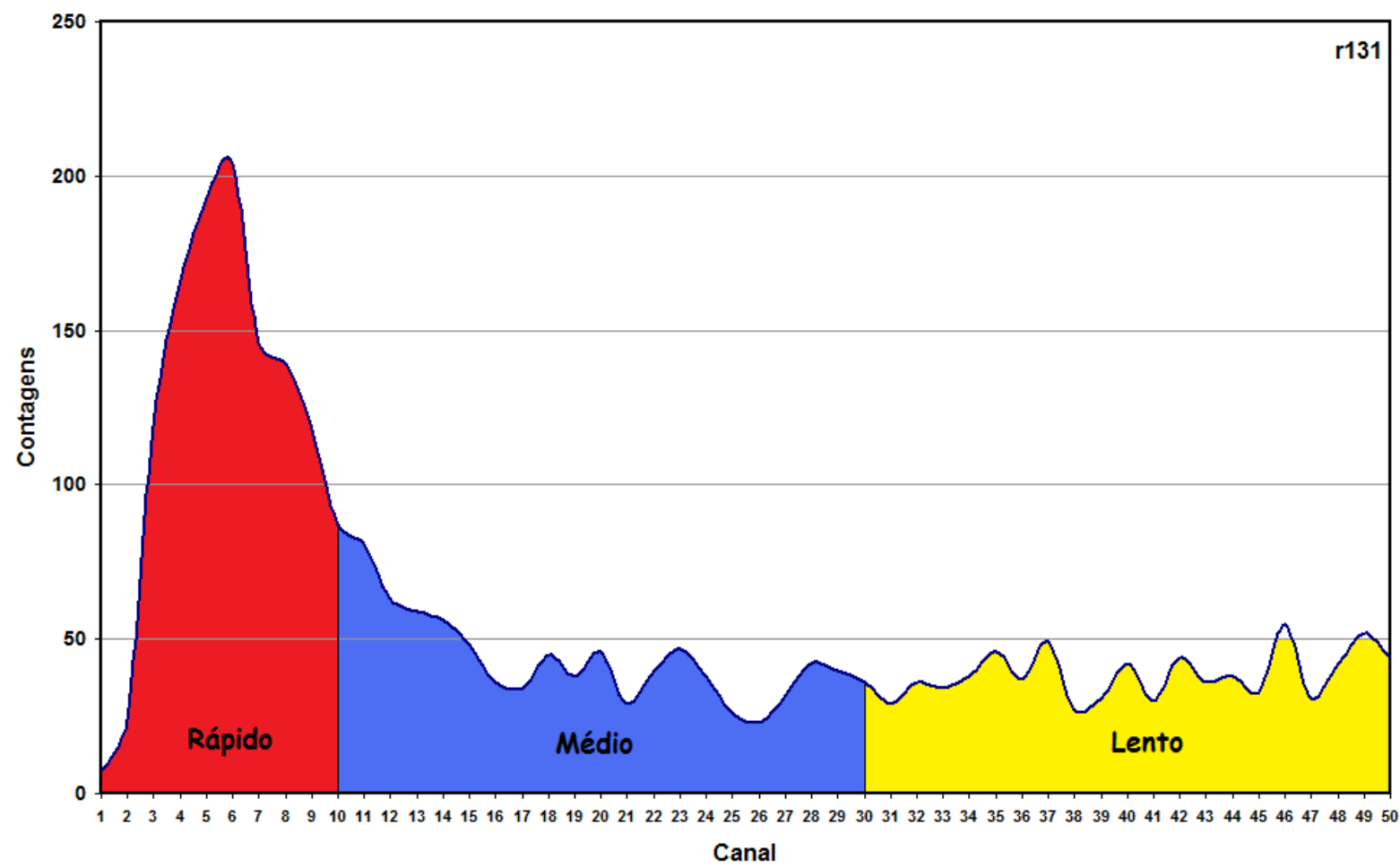

Figura 1: Divisão da curva LOE em três intervalos, informalmente chamados de rápido (1-10), médio (10-30) e lento $(30-50)$. 
(contagens/canal), lento (contagens/canal) que contabilizam os valores absolutos de cada classe; e rápido/lento, rápido/médio e médio/lento, que são as razões entre estas últimas variáveis; foram organizados e analisados por unidades estratigráficas e fácies. Ajustes de curvas exponenciais para computar a contribuição de cada componente não foram usados devido ao grande número de curvas LOE utilizadas neste estudo (>700). Curvas LM-LOE de discos vazios foram usadas para medir o background.

\section{III.5.Análise estatística descritiva de índices de minerais pesados e medidas LOE}

Para cada amostra, foram calculados os índices ZTR, ZTi, ZRi e ATi. Os valores dos índices foram categorizados por unidades estratigráficas (formações Guarda Velha, Varzinha, Pedra Pintada e Serra do Apertado) e fácies sedimentares (eólico e fluvial) e resumidos por estatísticas descritivas (média, desvio padrão, quartis, mediana, máximo e mínimo) gráficos Boxplot. Foram calculadas as mesmas estatísticas para as medidas LOE (intensidade total; intensidade dos componentes rápido (1-10), médio (10-30) e lento (30-50); porcentagens e contagens/canal e razões rápido/lento, rápido/médio e médio/lento), também categorizados por unidades estratigráficas e fácies. 


\section{REVISÃO BIBLIOGRÁFICA}

\section{IV.1.Geologia da Área de Estudo}

\section{IV.1.1.CONTEXTO TECTONO-ESTRATIGRÁFICO}

A Bacia do Camaquã está localizada na região centro-sul do Rio Grande do Sul (Figura 2) e trata-se de uma bacia distensional do tipo rifte (Fragoso-Cesar 1991, FragosoCesar et al. 1999, Paim et al. 2000). O Grupo Guaritas (Supergrupo Camaquã) ocorre alojado, em contato tectônico, entre os altos do embasamento da serra das Encantadas e de Caçapava do Sul, sendo que recobre parcialmente este último alto estrutural. Seus depósitos sedimentares são representados por uma faixa de direção NNE-SSW, com cerca de $50 \mathrm{~km}$ de largura e mais de $150 \mathrm{~km}$ de extensão, a qual é recoberta por depósitos permianos da Bacia do Paraná em suas extremidades. O embasamento do Grupo Guaritas aflora a sudeste, sendo constituído por complexos metamórficos e plutônicos das unidades brasilianas da região, as quais incluem o flanco ocidental do Cinturão Dom Feliciano e seu limite com o Terreno Rio Vacacaí, além do extremo setentrional do Cráton do Rio de La Plata (Fragoso-Cesar 1980, 1991). As estruturas tectônicas desse embasamento foram reativadas diversas vezes, durante e após a instalação do rifte (Almeida 2005, Almeida et al. 2009).

Além de rochas ígneas e metamórficas, o Grupo Guaritas sobrepõe-se a sucessões não-metamórficas com mais de $10 \mathrm{~km}$ de espessura das unidades mais antigas do Supergrupo Camaquã, as quais foram deformadas de modo rúptil e dispostas em camadas com direções em torno de NNE-SSW e mergulhos entre $20^{\circ}$ e $50^{\circ}$ ou localmente sub-verticais (Almeida 2005, Almeida et al. 2009). Segundo estes autores, estas sucessões foram depositadas na Bacia do Camaquã durante o período Ediacarano e compõem as seguintes unidades: Grupo Maricá (siliciclástico), Grupo Bom Jardim (vulcânico e siliciclástico), Formação Acampamento Velho (vulcânica) e Grupo Santa Bárbara (siliciclástico). A Bacia do Camaquã foi compartimentada em três sub-bacias durante a sedimentação do Grupo Santa Bárbara: Camaquã Ocidental, Camaquã Central e Camaquã Oriental, sendo que a estruturação da SubBacia Camaquã Central coincide com a do rifte ao tempo da deposição do Grupo Guaritas (Almeida 2005, Almeida et al. 2009). 


\section{IV.1.2.O GRUPO GUARITAS}

O Grupo Guaritas (Figura 3), correspondente ao topo do Supergrupo Camaquã, é formado por arenitos conglomeráticos, conglomerados, ritmitos areno-pelíticos e arenitos finos a médios com séries métricas de estratificação cruzada ou plano-paralela, interpretados como registro de sistemas deposicionais continentais (Robertson 1966, Lavina et al. 1985, Paim 1994, Almeida 2005). Seus arenitos apresentam intensa cimentação carbonática e correspondem, principalmente, a arcóseos e subarcóseos e, subordinadamente, a arenitos líticos (De Ros et al. 1994, Almeida 2005, Nóbrega et al. 2008).

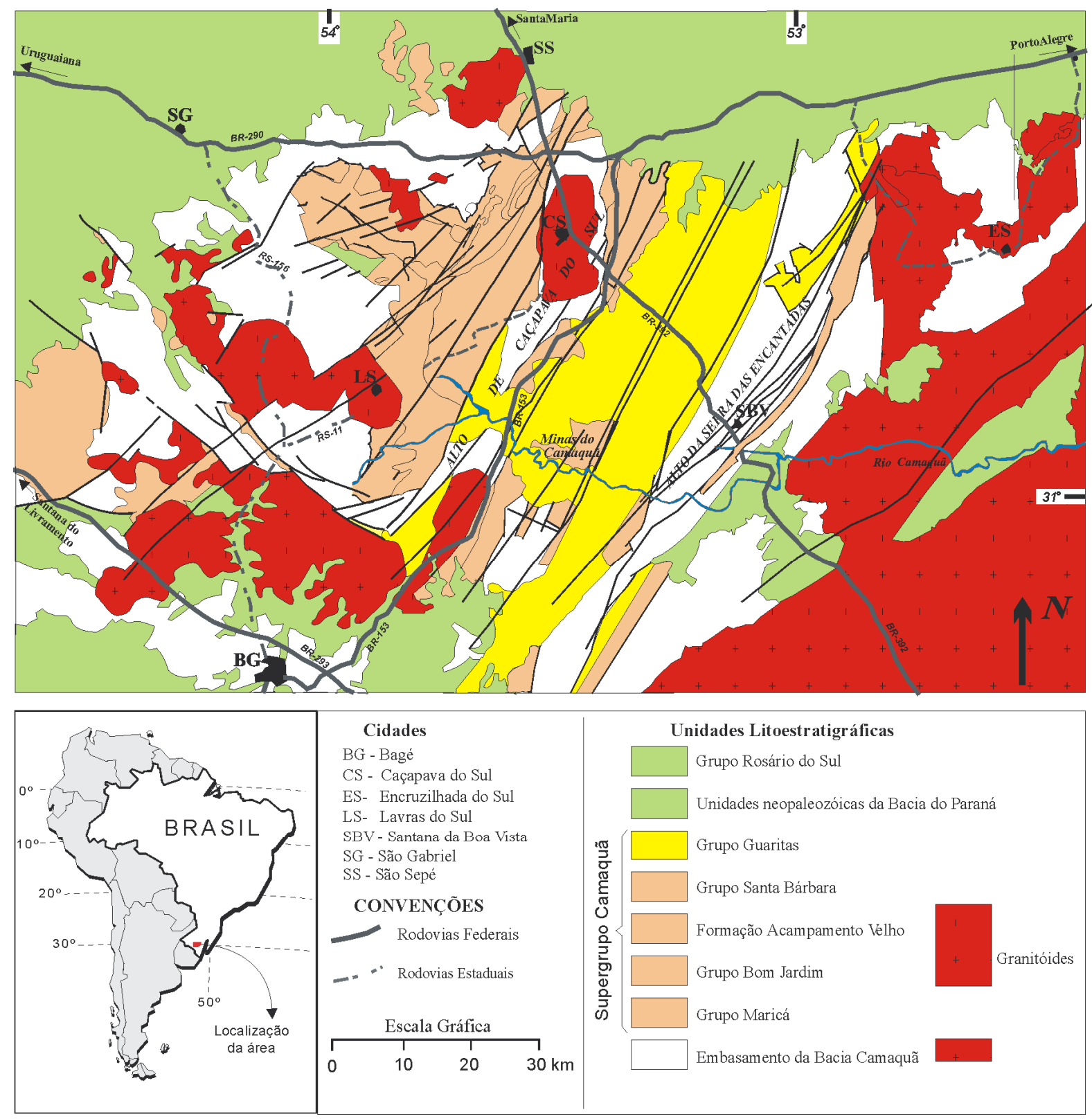

Figura 2: Mapa geológico esquemático da Bacia do Camaquã e áreas vizinhas (modificado de Almeida 2005). 
O Grupo Guaritas possui arenitos, interpretados como depósitos de dunas eólicas, os quais foram responsáveis por imprecisões nas colunas estratigráficas e nos mapas da década de 1960. A definição inicial da Formação Guaritas (Robertson 1966) excluía os depósitos eólicos, que foram cartografados como parte da então designada Formação Santa Bárbara por Ribeiro et al. (1966). O primeiro trabalho em que consta a interpretação de origem eólica para arenitos da Formação Guaritas resultou de mapeamento geológico na região do Passo do Tigre, no extremo sudoeste da Bacia do Camaquã (Becker \& Fernandes 1982).

Fragoso-Cesar et al. (1984) e Fragoso-Cesar et al. (1985) registraram a presença de depósitos eólicos na região das Minas do Camaquã, atribuídos a dunas barcanas. Lavina et al. (1985) distinguiram depósitos de dunas, caracterizadas pelos padrões de estratificação descritos por Hunter (1977, 1981), e interdunas, caracterizadas por camadas com estratificações horizontais e intercalações de pelitos gretados.

Faccini et al. (1987) identificaram a presença de abundantes fácies de marcas onduladas, interpretadas como de fluxo oscilatório em ambiente praial, intercaladas às sucessões eólicas.

Paim (1994) realizou estudos detalhados nas principais exposições de arenitos eólicos do Grupo Guaritas, dividindo a sucessão eólica em três associações de fácies: (i) arenitos com estratificações cruzadas, (ii) depósitos horizontais heterolíticos delgados e (iii) depósitos horizontais heterolíticos espessos.

Paim et al. (1995) e Paim (1996) discutiram a subdivisão aloestratigráfica de toda a Bacia do Camaquã, com breves considerações acerca da sucessão eólica. Paim (1996) ainda destacou a importância das fácies de interdunas úmidas para a interpretação paleoambiental da sucessão eólica, caracterizando-a como um sistema eólico úmido.

Paim \& Scherer (2003) detalharam as interpretações de sistemas deposicionais e de evolução estratigráfica da seção-tipo da Formação Pedra Pintada, caracterizando associações de fácies flúvio-lacustre, de dunas eólicas e de interdunas. Essa divisão, suas descrições e interpretações são compatíveis à proposta por Almeida (2005), que detalhou as associações de fácies de dunas eólicas e interdunas e expandiu a identificação de super-superfícies e a caracterização da arquitetura deposicional na seção-tipo da unidade (Paim \& Scherer 2003). Quanto à posição estratigráfica das sucessões eólicas, Almeida (2005) discorda daquela que foi considerada por Paim (1994), Paim et al. (1995, 2000) e Paim \& Scherer (2003). Enquanto Almeida et al. (2009) revelam que toda a sucessão eólica (Formação Pedra Pintada) tem posicionamento estratigráfico inferior às sucessões aluviais (Formação Serra do Apertado), com a sucessão com paleoventos para NNE sobre a sucessão com paleoventos para SSW, Paim (1994), Paim et al. (1995, 2000) e Paim \& Scherer (2003) consideram a 
existência de duas aloformações eólicas distintas, separadas por depósitos aluviais equivalentes às sucessões aluviais supracitadas. As duas unidades eólicas são reunidas na Formação Pedra Pintada por Almeida et al. (2009).

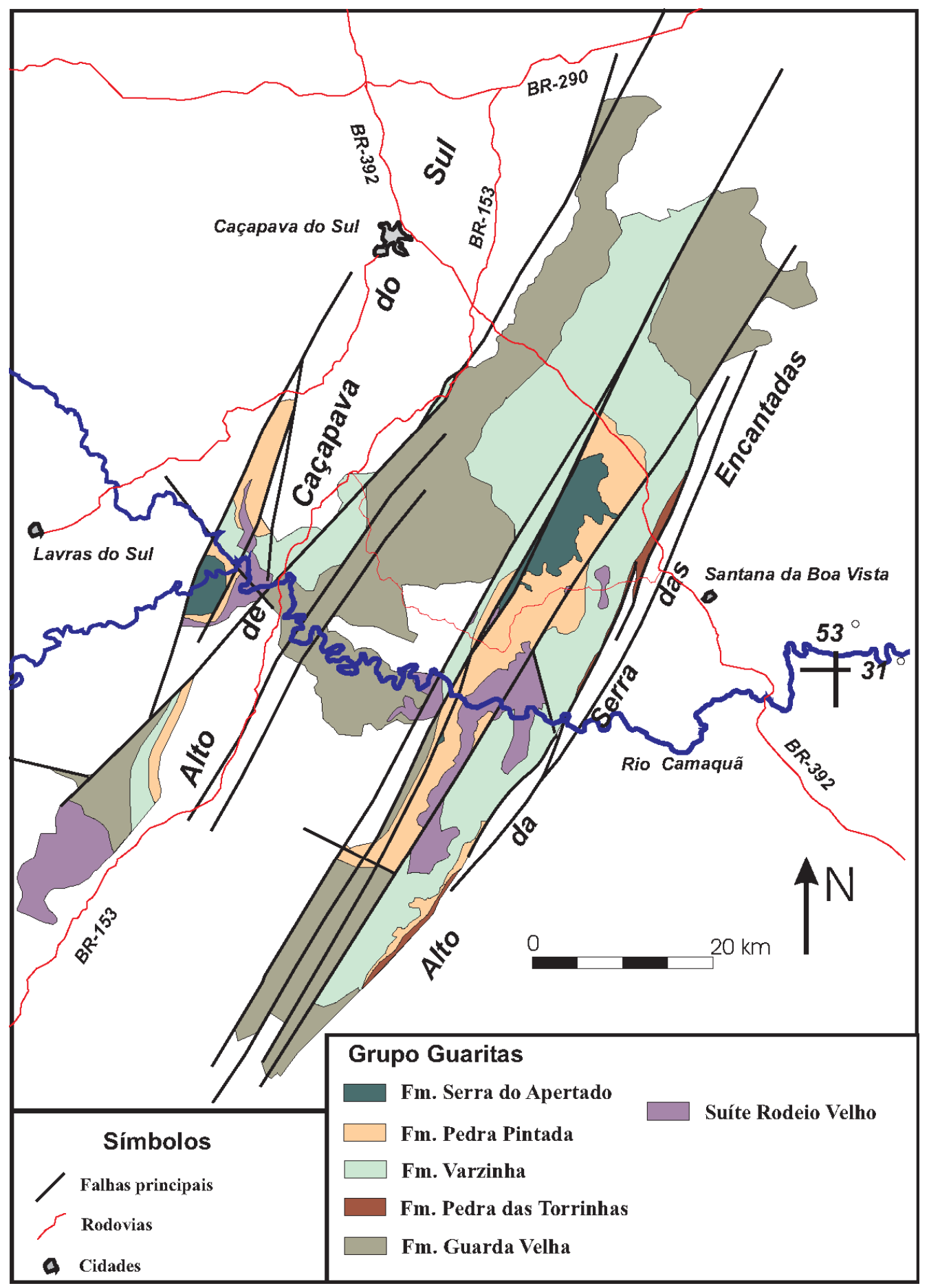

Figura 3: Mapa geológico do Grupo Guaritas (modificado de Almeida 2005).

Neste estudo, considera-se que o Grupo Guaritas teve sua deposição durante o Eocambriano, sendo adotada a subdivisão estratigráfica proposta por Almeida et al. (2009). De acordo com este autor, o Grupo Guaritas compreende as seguintes formações (Figura 4): 
Formação Guarda Velha: formada por arenitos, conglomerados e arenitos conglomeráticos de origem fluvial. Trata-se da unidade mais basal do Grupo Guaritas.

Formação Pedra das Torrinhas: formada por arenitos conglomeráticos e conglomerados atribuídos à fácies de leques aluviais. Esta unidade ocorre apenas nas bordas da bacia e apresenta proveniência derivada do embasamento adjacente.

Formação Varzinha: apresenta ritmitos psamo-pelíticos interpretados como fácies fluviais e aluviais distais. Ocorre em contato lateral com as formações Pedra das Torrinhas e Pedra Pintada.

Formação Pedra Pintada: possui arenitos finos com estratificação cruzada interpretados como fácies de dunas eólicas e raramente interdunas (arenitos finos com estratificação plano-paralela). Ocorrem também arenitos finos a grossos e arenitos conglomeráticos interpretados como fácies de canais de rios efêmeros.

Formação Serra do Apertado: é formada por arenitos finos a grossos e conglomerados de origem fluvial. É a unidade de topo do Grupo Guaritas.

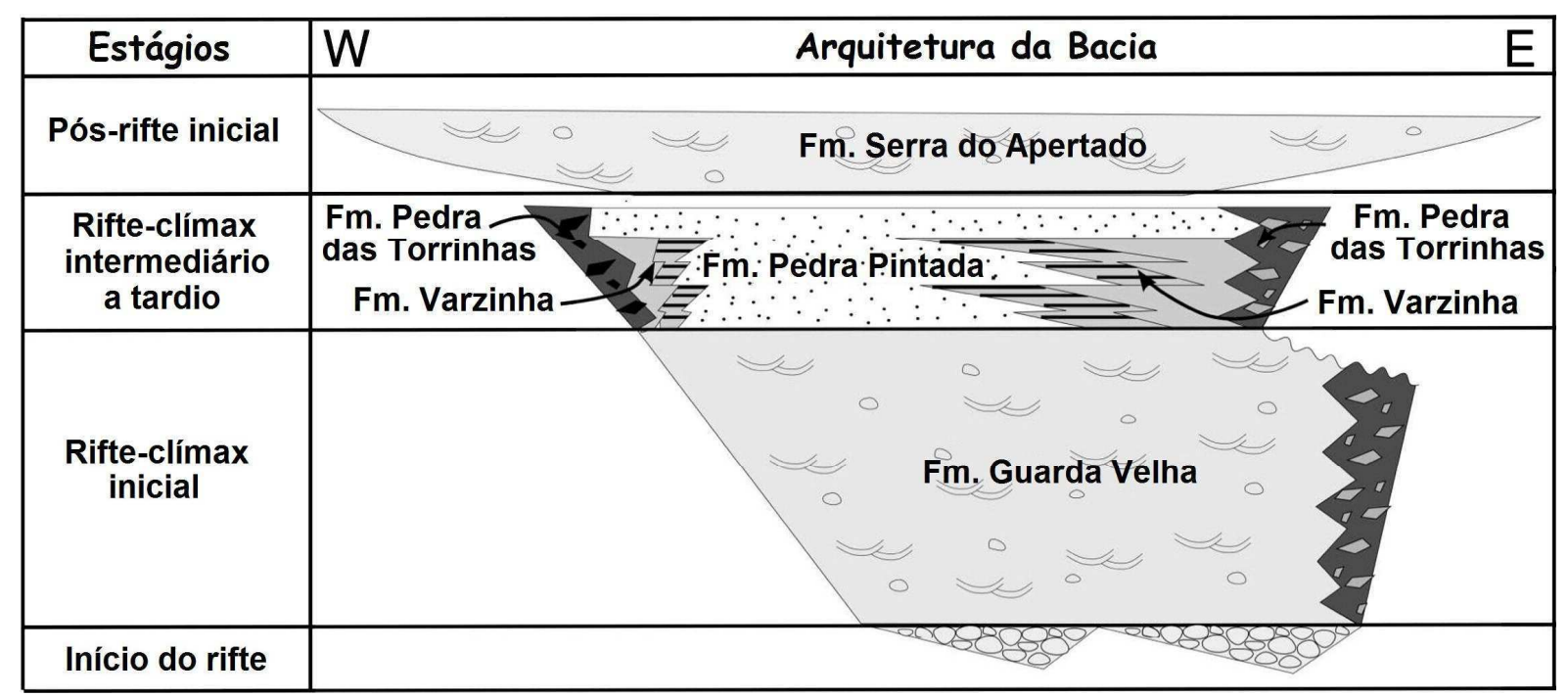

Figura 4: Carta estratigráfica esquemática do Grupo Guaritas (adaptada de Almeida et al. 2009).

\section{IV.2.Análise de proveniência sedimentar}

\section{IV.2.1.ASPECTOS GERAIS}

O termo proveniência vem do latim provenire, significando de onde veio, origem. Weltje \& von Eynatten (2004) consideram como análise de proveniência todo o tipo de investigação que possa ajudar a reconstruir a litosfera da Terra. Em geologia sedimentar, esse termo tem sido usado para unir diversos fatores relacionados à produção do sedimento, com especial atenção à composição das rochas fontes, assim como ao ambiente geológico e ao clima atuante na área fonte do sedimento. O objetivo do estudo de proveniência é reconstruir 
e interpretar a história do sedimento desde a erosão inicial da rocha fonte até a deposição final de seus detritos, ou seja, construir a árvore genealógica do sedimento. Com o estudo da proveniência pode-se deduzir as características das áreas fontes por meio das propriedades composicionais e texturais dos sedimentos e, junto com outros métodos de pesquisa, caracterizar a possível relação entre unidades geológicas separadas espacialmente.

A caracterização da proveniência dos sedimentos independe da idade geológica, sendo controlada por alterações texturais e composicionais ocorridas durante as etapas de intemperismo da rocha fonte, erosão, transporte e alteração pós-deposicional (Pettijohn 1941). A diagênese e o metamorfismo, por exemplo, recristalizam minerais e alteram as características texturais e composicionais primárias ou ainda formam novos minerais, mudando a assembléia mineralógica deposicional do sedimento. No caso da composição da assembléia de minerais pesados, esta pode ser alterada pela remoção dos minerais mais instáveis ao intemperismo, por abrasão durante o transporte e perdas causadas por dissolução após a sedimentação (dissolução intraestratal) (Pettijohn 1975).

A análise de proveniência de rochas arenosas pode ser feita através da caracterização da assembléia de minerais pesados e dos componentes principais do arcabouço (quartzo, feldspato e fragmentos líticos), os quais na maioria das vezes fornecem informações indiretas acerca das rochas fontes. Além da assembléia de minerais pesados, razões entre minerais (Morton \& Hallsworth 1994, 1999) e grau de maturidade textural (e.g. Nascimento et al. 2007) podem ser utilizadas para a inferência de áreas fontes ou correlação entre unidades. Estudos recentes têm demonstrado que a sensibilidade LOE (Luminescência Opticamente Estimulada) do quartzo relaciona-se à sua história deposicional (Pietsch et al. 2008; Sawakuchi et al. 2010). Assim, a sensibilidade LOE permite a discriminação de grãos de quartzo de diferentes origens. Já em rochas conglomeráticas, o menor grau de fragmentação do cascalho pode fornecer informações diretas acerca das rochas fontes. Além disto, possibilita a observação de rochas que seriam dificilmente reconhecidas através da análise de minerais pesados, tais como quartzito e quartzo de veio.

\section{IV.2.2.ÍNDICES BASEADOS EM MINERAIS PESADOS}

Hubert (1962) definiu o índice ZTR (somatório das proporções de zircão, turmalina e rutilo dentre os minerais pesados transparentes não-micáceos) como indicador de maturidade mineralógica de sedimentos arenosos, o qual poderia ser usado para correlação entre unidades sedimentares. No entanto, o índice ZTR combina minerais resistentes à dissolução química (zircão, turmalina e rutilo), porém com densidades relativamente distintas, o que implica susceptibilidade variável destes minerais ao transporte sedimentar. Assim, as variações do 
índice ZTR podem resultar do efeito combinado da alteração pós-deposicional e do transporte sedimentar. Isto dificulta sua interpretação em termos de proveniência sedimentar e sua utilização para correlação entre unidades estratigráficas. Morton \& Hallsworth $(1994,1999)$ forneceram parâmetros para comparação entre unidades sedimentares por meio da razão entre tipos específicos de minerais pesados. O significado genético destes índices depende do contraste entre as características químicas (resistência à dissolução) e físicas (resistência à abrasão, forma e densidade) dos minerais que compõem o respectivo índice. O índice ZRi (100 x grãos de zircão/(grãos de rutilo + zircão)), por exemplo, seria indicativo de mudanças de área-fonte primária, já que reúne minerais com características químicas e físicas semelhantes, portanto, pouco susceptível à modificações pelo transporte sedimentar e alteração pós-deposicional. O índice ATi (100 x grãos de apatita/(grãos de turmalina + apatita)), seria indicativo de mudanças na assembléia durante a diagênese e o intemperismo, pois reúne minerais com características químicas e físicas distintas, mas com densidades semelhantes. Baseado em Morton \& Hallsworth (1994), Guedes et al. (2011) definiu o índice formado pela razão entre o número de grãos de zircão e o número de grãos de turmalina+zircão (ZTi). O contraste de densidade entre zircão $\left(4,6\right.$ a 4,7 g/ $\left.\mathrm{cm}^{3}\right)$ e turmalina $\left(2,9\right.$ a $\left.3,1 \mathrm{~g} / \mathrm{cm}^{3}\right)$ torna os grãos de turmalina mais susceptíveis ao transporte em relação aos grãos de zircão, o que tornaria a unidade fonte relativamente rica em zircão. Seguindo este raciocínio, este índice seria indicador do grau de retrabalhamento sedimentar, sendo que sedimentos mais retrabalhados apresentariam valores maiores de ZTi, devido à concentração residual de zircão na fonte.

\section{IV.2.3.LUMINESCÊNCIA DO QUARTZO}

Luminescência é o fenômeno de emissão de luz por um material exposto a um agente excitante. O comprimento de onda da luz emitida é característico do material luminescente e não do agente excitante (McKeever 1985). Termoluminescência (TL) e luminescência opticamente estimulada (LOE) são fenômenos de luminescência. A TL/LOE ocorre quando certos materiais que foram previamente expostos à radiação ionizante são estimulados por calor/luz. Em ambos os fenômenos a intensidade da emissão de luz é em geral proporcional à quantidade ou dose absorvida de radiação ionizante a que o material foi previamente exposto. A teoria de banda ionizante cria pares elétron-buraco. Os elétrons e buracos movem-se nas bandas de condução e valência e podem ser capturados em defeitos da rede cristalina. Esses defeitos são, em geral, níveis localizados de energia na banda proibida e são chamados de armadilhas de elétrons e centros de recombinação, os quais são estáveis em temperatura ambiente. Fornecendo energia térmica/óptica ao sistema de forma controlada, aumenta-se a 
probabilidade dos portadores de cargas (elétrons/buracos) escaparem de suas respectivas armadilhas. Dessa forma, as cargas promovidas à banda de condução ou valência movem-se livremente pelo cristal podendo ser recapturadas ou recombinarem-se com sua parte contrária. Dessa recombinação resulta a liberação de energia através da emissão de luz. A emissão de luz pode ser detectada e amplificada através de uma fotomultiplicadora e é relacionada com a dose absorvida na qual o material foi exposto. Os defeitos no retículo cristalino responsáveis pela TL e LOE são formados pela incorporação de íons estranhos (impurezas) a determinado cristal (Preusser et al. 2009). Aquecimentos ocorridos após a cristalização ou exposição a elevadas doses de radiação ionizante podem modificar a distribuição das impurezas no retículo cristalino e alterar a luminescência do quartzo. Assim, a TL/LOE do quartzo relaciona-se tanto à sua temperatura e ambiente de cristalização quanto à sua história termal e de irradiação. Isto possibilitaria o uso da TL/LOE como traçador em materiais sedimentares (Rink 2003).

Pietsch et al. (2008) demonstraram que durante o transporte fluvial, os grãos de quartzo têm sua sensibilidade LOE incrementada a cada ciclo de soterramento/transporte. Esse incremento é cumulativo e indica que quanto maiores os valores da sensibilidade LOE, mais retrabalhados foram esses grãos. Este aumento de sensibilidade LOE ocorre principalmente pela elevação do componente LOE rápido, que é aumentada em relação aos demais componentes (Sawakuchi et al. 2010). Os valores de sensibilidade LOE permitem medir o retrabalhamento sedimentar em grãos individuais de quartzo, enquanto que os índices de minerais pesados representariam a média do retrabalhamento de uma mistura de sedimentos. 


\section{RESULTADOS}

\section{V.1.Fácies Sedimentares}

As etapas de campo (Figura 5A) tiveram como objetivos a coleta de amostras para as análises petrográficas e de luminescência, a realização de descrição de fácies sedimentares (figuras 6 e 7) e seu posicionamento estratigráfico.

Nas formações Guarda Velha e Serra do Apertado foi identificada apenas fácies ACc, que corresponde a arenitos conglomeráticos a conglomerados com estratificação cruzada acanalada em séries que variam de decimétricas a métricas. Esta fácies foi interpretada como formada por migração de barras de cascalho sob regime de fluxo inferior em sistemas fluviais entrelaçados.

$\mathrm{Na}$ Formação Varzinha foram identificadas a fácies ACc descrita acima e a fácies AFph, que consiste de arenitos finos, às vezes siltosos/micáceos, com estratificação planoparalela e laminação heterolítica. A fácies AFph é interpretada como depósitos associados à planície de inundação em sistemas fluviais entrelaçados.

Na Formação Pedra Pintada foram identificadas as fácies AFc (arenito fino com estratificação cruzada acanalada em séries decimétricas a métricas, com gênese atribuída à migração de dunas barcanóides) e AFp (arenito fino com estratificação plano-paralela em séries decimétricas, com deposição em depressão interdunar seca), sendo ambas interpretadas como parte de um sistema eólico em associação de fácies de campo de dunas. Ainda nesta formação, foi identificada a fácies AFpg, constituída de arenito fino com estratificação planoparalela em séries métricas, com níveis pelíticos gretados ou contínuos, interpretada como sendo formada pela acumulação de areia em planície interdunar susceptível à períodos de inundação em sistema deposicional eólico (associação de fácies de planície interdunar). Também foi identificada nesta formação, a fácies AGp (arenito com grânulos e seixos e estratificação plano-paralela), interpretada como depositada em planície interdunar com deflação ou fluxo aquoso (regime de fluxo superior) em sistema fluvial entrelaçado. 

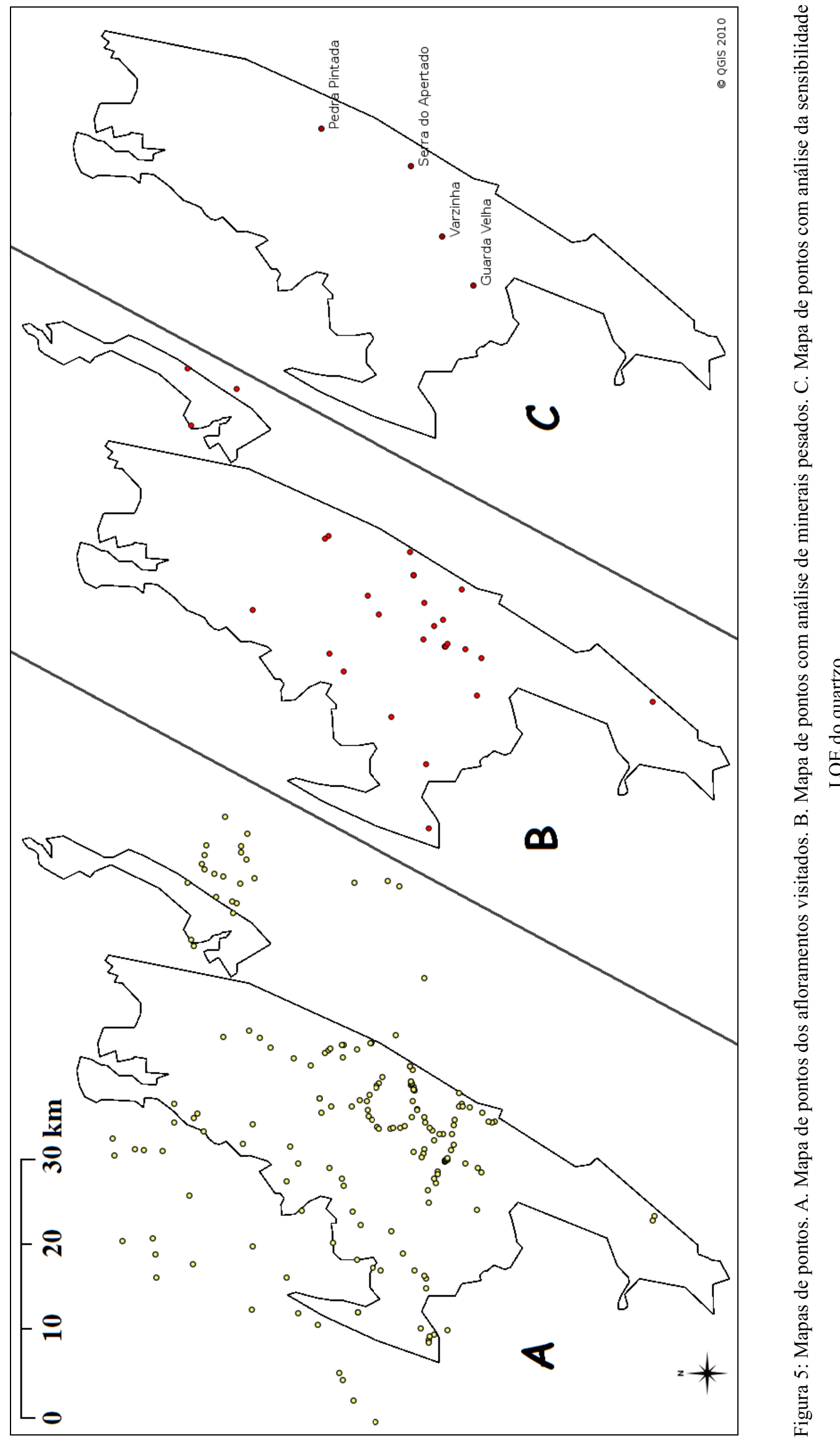
No total foram reconhecidas 6 fácies agrupadas em 2 sistemas deposicionais (Tabela 2).

Tabela 2: Fácies sedimentares das formações Varzinha, Pedra Pintada, Pedra da Arara e Serra do Apertado, amostradas para petrografia de seções delgadas e análises de minerais pesados e de luminescência do quartzo. As letras maiúsculas das siglas das fácies referem-se à características granulométricas e as letras minúsculas às estruturas sedimentares diagnósticas.

\begin{tabular}{|c|c|c|c|}
\hline Fácies sedimentares & Processo & $\begin{array}{c}\text { Unidades } \\
\text { estratigráficas }\end{array}$ & $\begin{array}{c}\text { Sistemas } \\
\text { deposicionais }\end{array}$ \\
\hline $\begin{array}{l}\text { Arenito fino com estratificação } \\
\text { cruzada acanalada em séries } \\
\text { decimétricas a métricas (AFc). }\end{array}$ & $\begin{array}{l}\text { A gênese desta fácies é } \\
\text { atribuída à migração de } \\
\text { duna eólica de crista } \\
\text { sinuosa (barcanóide). }\end{array}$ & Fm. Pedra Pintada & $\begin{array}{c}\text { Sistema eólico - } \\
\text { associação de fácies de } \\
\text { campo de dunas }\end{array}$ \\
\hline $\begin{array}{l}\text { Arenito fino com estratificação } \\
\text { plano-paralela em séries métricas } \\
\text { (AFpg). Ocorrem níveis pelíticos } \\
\text { gretados ou contínuos. }\end{array}$ & $\begin{array}{c}\text { Fácies formada pela } \\
\text { acumulação de areia em } \\
\text { planície interdunar } \\
\text { susceptível à períodos de } \\
\text { inundação. }\end{array}$ & Fm. Pedra Pintada & $\begin{array}{c}\text { Sistema eólico - } \\
\text { associação de fácies de } \\
\text { planície interdunar }\end{array}$ \\
\hline $\begin{array}{c}\text { Arenito conglomerático e } \\
\text { conglomerado com estratificação } \\
\text { cruzada acanalada em séries } \\
\text { decimétricas a métricas (ACc). }\end{array}$ & $\begin{array}{l}\text { Fácies formada por } \\
\text { migração de barras de } \\
\text { cascalho sob regime de } \\
\text { fluxo inferior. }\end{array}$ & $\begin{array}{c}\text { Fm. Serra do Apertado } \\
\text { Fm. Varzinha } \\
\text { Fm. Guarda Velha }\end{array}$ & $\begin{array}{l}\text { Sistema fluvial } \\
\text { entrelaçado }\end{array}$ \\
\hline $\begin{array}{l}\text { Arenito fino com estratificação } \\
\text { plano-paralela e laminação } \\
\text { heterolítica (AFph). Associa-se à } \\
\text { fácies ACc. }\end{array}$ & $\begin{array}{l}\text { Depósitos associados à } \\
\text { planície de inundação. }\end{array}$ & Fm. Varzinha & $\begin{array}{l}\text { Sistema fluvial } \\
\text { entrelaçado }\end{array}$ \\
\hline $\begin{array}{l}\text { Arenito fino com estratificação } \\
\text { plano-paralela em séries } \\
\text { decimétricas (AFp). Associa-se à } \\
\text { fácies AFc. }\end{array}$ & $\begin{array}{c}\text { Deposição de areia em } \\
\text { depressão interdunar seca. }\end{array}$ & Fm. Pedra Pintada & $\begin{array}{c}\text { Sistema eólico - } \\
\text { associação de fácies de } \\
\text { campo de dunas }\end{array}$ \\
\hline $\begin{array}{c}\text { Arenito com grânulos e seixos e } \\
\text { estratificação plano-paralela } \\
\text { (AGp). }\end{array}$ & $\begin{array}{l}\text { Planície interdunar com } \\
\text { deflação ou fluxo aquoso } \\
\text { (regime de fluxo superior). }\end{array}$ & Fm. Pedra Pintada & $\begin{array}{l}\text { Sistema fluvial } \\
\text { entrelaçado }\end{array}$ \\
\hline
\end{tabular}



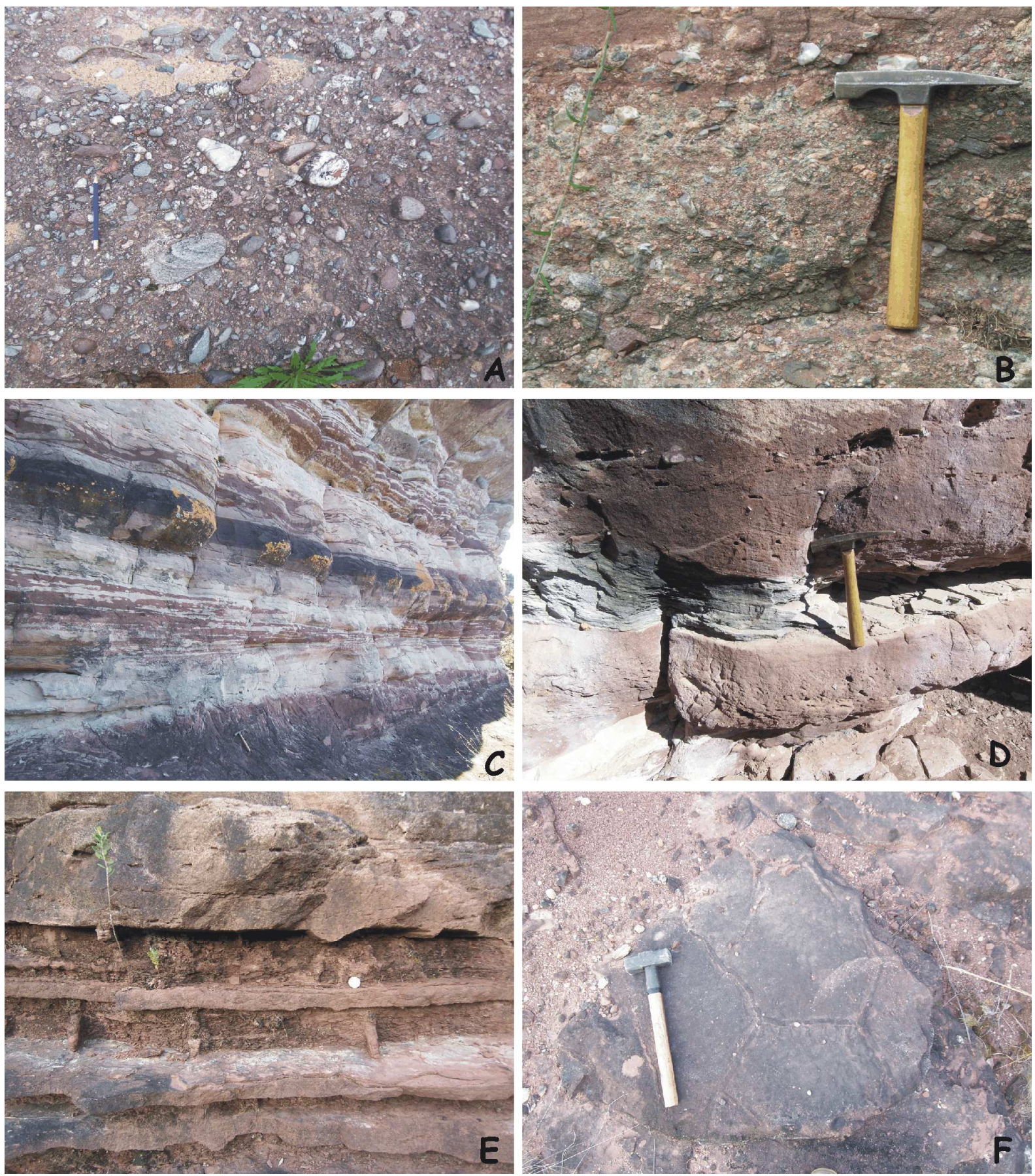

Figura 6: Fotos de fácies. A e B: Conglomerado a arenito conglomerático (fácies ACc) das formações Guarda

Velha e Varzinha, respectivamente. C a F: Arenito fino com estratificação plano-paralela e laminação heterolítica (fácies AFph) da Formação Varzinha. Notar gretas de contração nas fotos E e F. 

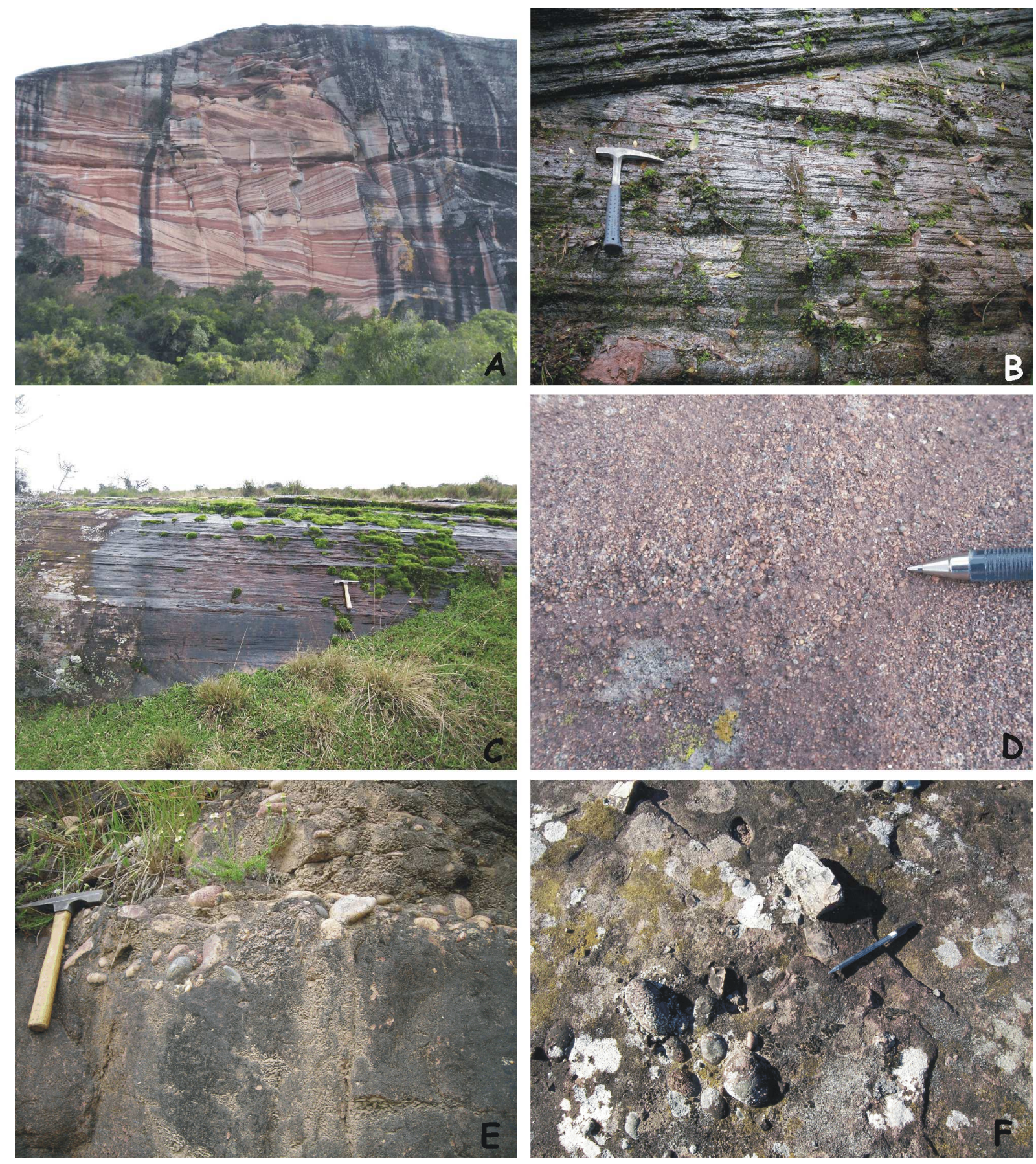

Figura 7: Fotos de fácies. A a E: Formação Pedra Pintada; F: Formação Serra do Apertado. A e B: Arenito fino com estratificação cruzada acanalada em séries decimétricas a métricas (fácies $\mathrm{AFc}$ ). $\mathrm{C}$ : Arenito fino com estratificação plano-paralela em séries métricas (AFpg). D: Superfície de deflação associada a fácies AFp (Arenito fino com estratificação plano-paralela em séries decimétricas). E: Arenito com grânulos e seixos e estratificação plano-paralela (AGp). F: Arenito conglomerático e conglomerado com estratificação cruzada acanalada em séries decimétricas a métricas (ACc). 


\section{V.2.Petrografia de seções delgadas}

Foram confeccionadas 20 seções delgadas de amostras de arenitos que contemplaram as formações Guarda Velha, Varzinha, Pedra Pintada e Serra do Apertado e que são representativas da área geográfica abrangida pelo estudo (figuras 8 e 9). As rochas do Grupo Guaritas correspondem a arcóseos, subarcóseos e arcóseos líticos (sensu Folk 1968) e as principais características texturais e mineralógicas das amostras estudadas são descritas a seguir.

Formação Guarda Velha - fácies ACc (Lâmina P35): arcóseo a arcóseo lítico, com fragmentos líticos de quartzito, granito e xisto. Possui cimentação carbonática. $\mathrm{O}$ arcabouço é composto predominantemente por grãos sub-angulosos e pequena quantidade de grãos sub-arredondados e angulosos.

Formação Varzinha - fácies ACc e AFph (Lâminas P01, P03, P06, P30, P32, P39): arcóseos a arcóseos líticos com fragmentos de quartzito, granito, xisto e arenito, às vezes milimétricos. Possuem cimentação carbonática, com cimentação ferrugionosa associada. Arcabouço com predomínio de grãos sub-angulosos e ocorrência de grãos subarredondados e angulosos.

Formação Pedra Pintada - fácies AFc e AFp (Lâminas P08A, P15, P18, P25A, P29, P40 e P43) - fácies AFpg e AGp (Lâminas P08B, P12) - fácies AFp (Lâmina P20): arcóseos a sub-arcóseos, com cimentação carbonática e ferruginosa em menor proporção. A fácies AFp não apresentou fragmentos líticos, assim como a eólica, sugerindo controle granulométrico sobre a ocorrência de fragmentos líticos. Arcabouço formado por grãos sub-angulosos e sub-arredondados, com presença de grãos arredondados e angulosos em menor quantidade.

Formação Serra do Apertado - fácies ACc (Lâminas P27 e P25B): arcóseos a arcóseos líticos com fragmentos líticos de quartzito, xisto, granito e arenito, às vezes até milimétricos. A cimentação predominante é carbonática e ferruginosa em menor quantidade. O arcabouço é formado predominatemente por grãos sub-angulosos e contém também grãos sub-arredondados e angulosos. 

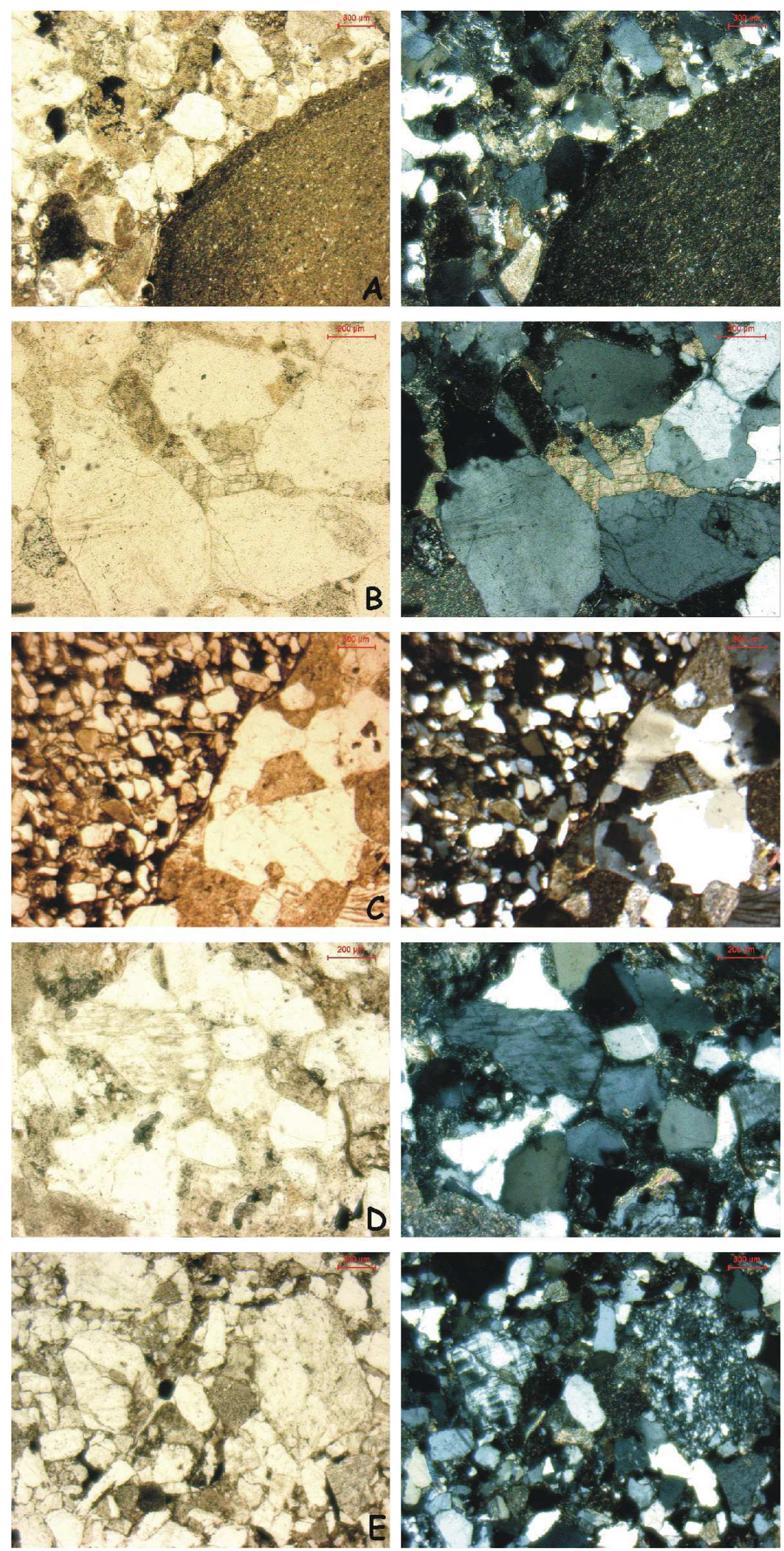

Figura 8: Fotos de seções delgadas. A e B: fácies ACc da Formação Serra do Apertado. C e D: fácies AFph da Formação Varzinha. E: fácies AGp da Formação Pedra Pintada. Notar grânulos de andesito e granito à direita nas fotos $\mathrm{A}$ e $\mathrm{C}$, respectivamente. 

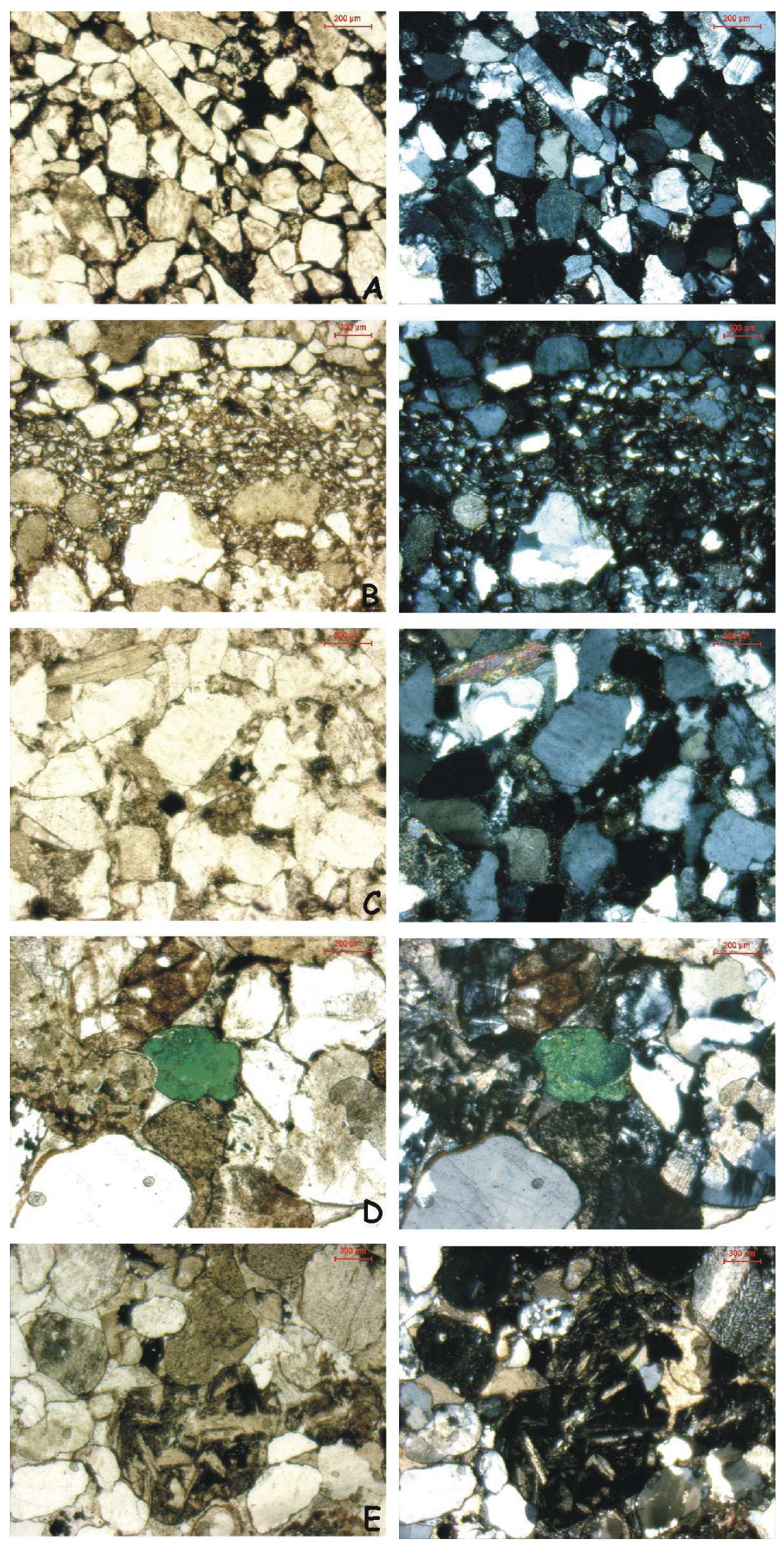

Figura 9: Fotos de seções delgadas. A: fácies AFpg na Fm. Pedra Pintada. Notar imbricamento dos grãos. B: laminação bimodal (pin stripe) presente na fácies AFc da Fm. Pedra Pintada. C: fácies AGp na Fm. Pedra Pintada. D e E: fácies ACc com fragmentos líticos (granito, andesito, filito) na Fm. Serra do Apertado. 


\section{V.3.Minerais Pesados}

\section{V.3.1.DESCRIÇÃO DA ASSEMBLÉIA DE MINERAIS PESADOS}

Os minerais pesados identificados foram: zircão, turmalina, rutilo, anatásio, apatita, granada, titanita, monazita, sillimanita, cianita e epídoto (figuras 10 e 11). Grãos de zircão, apatita, granada, turmalina, rutilo e anatásio dominam a assembléia de minerais pesados enquanto que grãos de titanita, monazita, sillimanita, cianita e epidoto ocorrem em proporções muito baixas (Tabela 3$)$. Destacam-se a grande variação dos teores de apatita (0 a 64\%), zircão (4 a 82\%), granada (0 a 91\%) e turmalina (1 a 41\%), os quais são mais freqüentes na assembléia de minerais pesados das unidades estudadas.

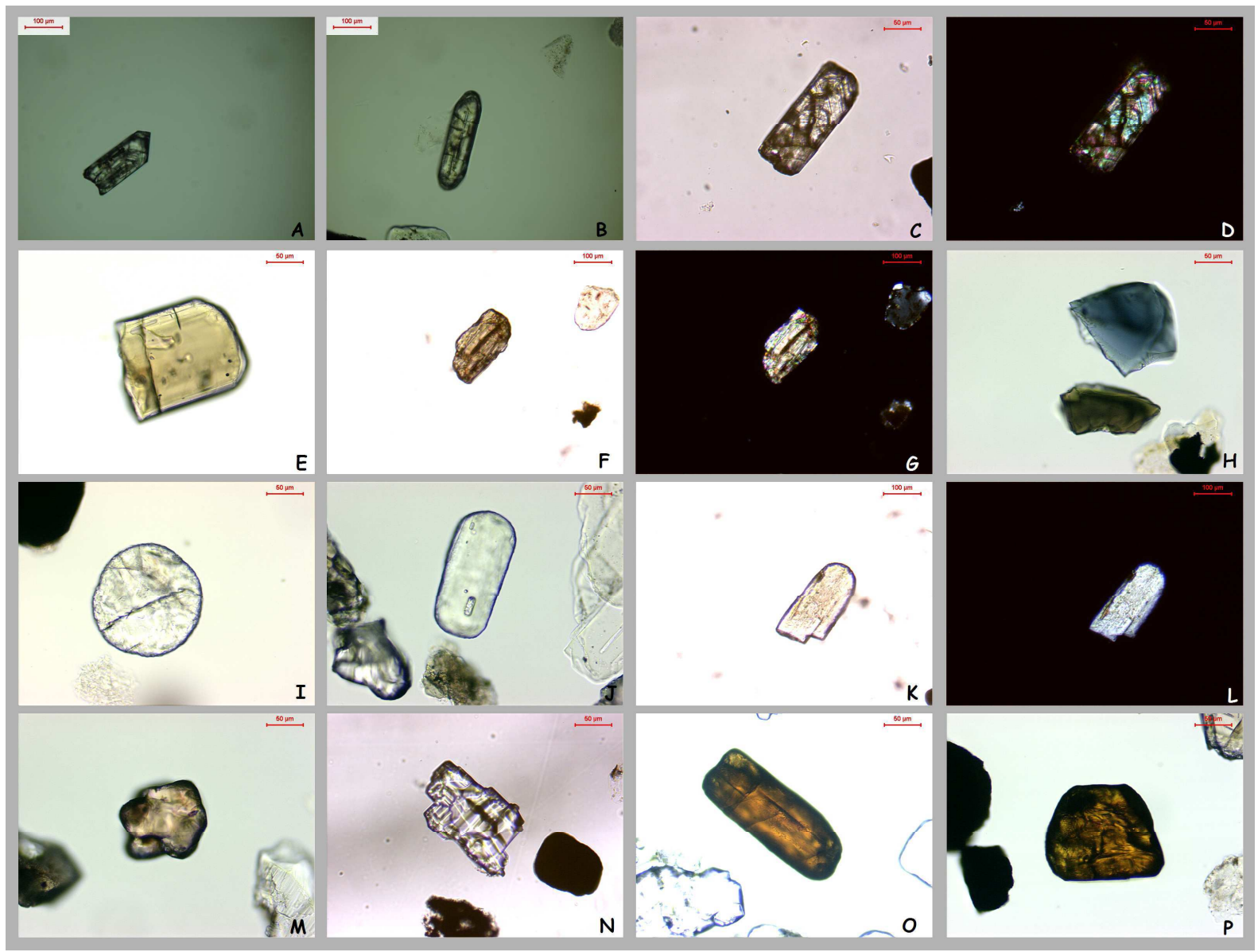

Figura 10: Minerais pesados identificados nas unidades do Grupo Guaritas: Zircão (A, B, C, D); Turmalina (E, F, G, H); Apatita (I, J, K, L); Granada (M, N); Rutilo (O, P) (nicóis paralelos em: A, B, C, E, F, H, I, J, K, M, N, O, P; nicóis cruzados em D, G, L). 


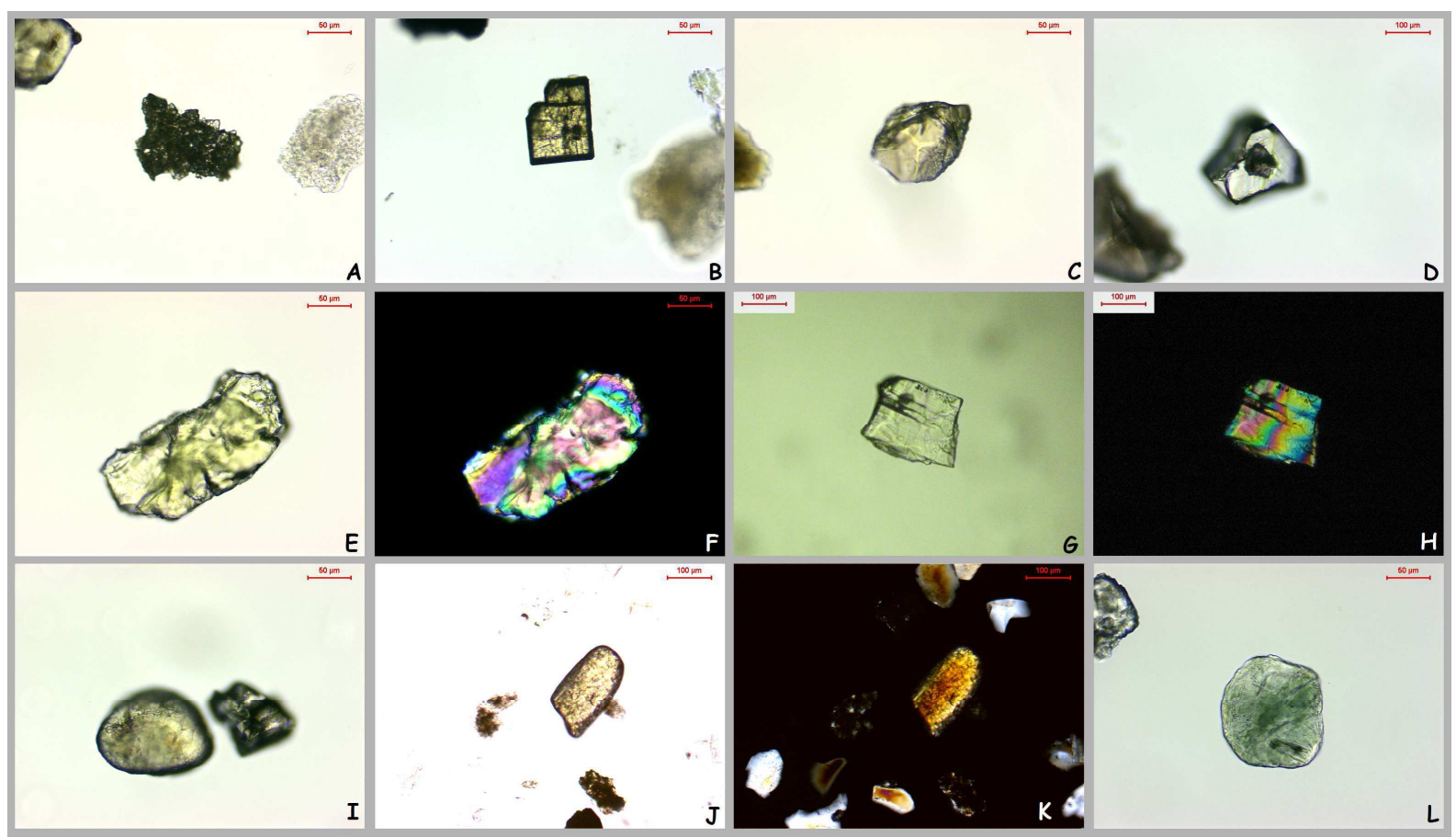

Figura 11: Minerais pesados identificados nas unidades do Grupo Guaritas: Anatásio (A, B); Titanita (C, D); Epidoto (E, F); Sillimanita (G, H); Monazita (I); Estaurolita (J, K); Hornblenda (L) (nicóis paralelos em: A, B, C, D, E, G, I, J, L; nicóis cruzados em F, H, K).

A Tabela 4 apresenta a variação da proporção dos minerais pesados observados nas unidades estudadas. Observa-se que a Formação Guarda Velha apresenta os menores máximos para os minerais ultraestáveis (zircão, turmalina e rutilo) e os maiores mínimos para os minerais apatita e granada, além da única ocorrência de estaurolita nas amostras analisadas. Já na Formação Pedra Pintada, foram observados os maiores máximos para os minerais zircão, turmalina, rutilo e apatita; e o menor máximo para o mineral granada. A cianita foi observada somente na Formação Varzinha. O epídoto foi observado nas formações Guarda Velha, Varzinha e Pedra Pintada. A hornblenda ocorre nas formações Pedra Pintada e Serra do Apertado. Todos os demais minerais observados (zircão, turmalina, rutilo, anatásio, apatita, granada, titanita, monazita e sillimanita) ocorrem em todas as formações.

\section{V.3.2.ÍNDICES DE MINERAIS PESADOS (ZTR, ZTi, ZRi E ATi)}

Foram calculados os índices ZTR, ZTi, ZRi e ATi para cada amostra (Figura 5B). Estatísticas descritivas (tabelas 5 e 6) permitiram classificar e comparar os sistemas deposicionais do Grupo Guaritas segundo a proveniência sedimentar primária e grau de 
retrabalhamento dos seus sedimentos. O índice ATi permite avaliar a alteração pósdeposicional de determinada amostra, permitindo inferir se foi significativamente afetada pelo intemperismo. Amostras alteradas apresentam índice ATi relativamente baixos (Figura 12) devido à alteração preferencial da apatita. Estas amostras foram retiradas das análises estatísticas. Desse modo, os índices ATi e ZTR foram contabilizados em apenas 24 das 44 amostras.

Tabela 3: Descrição e freqüência de ocorrência dos minerais pesados observados nas amostras do Grupo Guaritas.

\begin{tabular}{|c|c|c|c|c|}
\hline Mineral & Características Principais & $\begin{array}{l}\text { Média } \\
(\%)\end{array}$ & $\begin{array}{c}\text { Mínimo } \\
(\%)\end{array}$ & $\begin{array}{c}\text { Máximo } \\
(\%)\end{array}$ \\
\hline Zircão & $\begin{array}{l}\text { Bem arredondados a angulosos/euédricos. Prismas curtos ou } \\
\text { longos. Grãos com zoneamento interno são comuns. } \\
\text { Geralmente incolor, raramente em tons rosados }\end{array}$ & 36 & 4 & 82 \\
\hline Turmalina & $\begin{array}{l}\text { Superarredondados a subarredondados/subédricos, às vezes } \\
\text { fraturados. Cores verde, marrom (predominante) e azul. }\end{array}$ & 13 & 1 & 41 \\
\hline Rutilo & $\begin{array}{l}\text { Bem arredondados a arredondados. Apresentam tons } \\
\text { avermelhados, raramente amarelados. }\end{array}$ & 3 & 0 & 10 \\
\hline Apatita & $\begin{array}{l}\text { Grãos equidimensionais arredondados e prismáticos } \\
\text { subédricos. Incolor. }\end{array}$ & 23 & 0 & 64 \\
\hline Granada & $\begin{array}{l}\text { Grãos equidimensionais, mas sem forma bem definida, } \\
\text { apresentando feições geométricas de corrosão. Geralmente } \\
\text { incolor e subordinadamente em tons rosados. }\end{array}$ & 16 & 0 & 91 \\
\hline Anatásio & $\begin{array}{l}\text { Grãos anédricos, e grãos euédricos equidimensionais. Isolados } \\
\text { ou em aglomerados. }\end{array}$ & 7 & 0 & 28 \\
\hline Titanita & Arredondados a angulosos/euédricos. Em tons amarelados. & 1 & 0 & 11 \\
\hline Sillimanita & Angulosa a Anédrica. Incolor. & 1 & 0 & 5 \\
\hline Epídoto & Anédricos. Verde. & 0 & 0 & 2 \\
\hline Hornblenda & Anédricos. Verde. & 0 & 0 & 1 \\
\hline Estaurolita & Subarredondada e com feições de corrosão. Amarelada. & 0 & 0 & 1 \\
\hline Monazita & Arredondada a bem arredondada. Amarelada. & 0 & 0 & 4 \\
\hline Cianita & Anédricos. Incolor. & 0 & 0 & 1 \\
\hline
\end{tabular}


Tabela 4: Proporções médias, máximas e mínimas dos minerais pesados encontrados nas amostras das formações Guarda Velha, Varzinha, Pedra Pintada e Serra do Apertado.

\begin{tabular}{|c|c|c|c|c|c|}
\hline \multirow[b]{2}{*}{ Mineral } & \multicolumn{5}{|c|}{ Média (Mínimo-Máximo) (\%) } \\
\hline & $\begin{array}{c}\text { Grupo } \\
\text { Guaritas } \\
(\mathrm{N}=44)\end{array}$ & $\begin{array}{c}\text { Fm. Guarda } \\
\begin{array}{c}\text { Velha } \\
(\mathrm{N}=7)\end{array}\end{array}$ & $\begin{array}{c}\text { Fm. } \\
\text { Varzinha } \\
(\mathrm{N}=11)\end{array}$ & $\begin{array}{c}\text { Fm. Pedra } \\
\text { Pintada } \\
(\mathrm{N}=19)\end{array}$ & $\begin{array}{c}\text { Fm. Serra } \\
\text { do Apertado } \\
(\mathrm{N}=7)\end{array}$ \\
\hline Zircão & $36(4-82)$ & $16(5-39)$ & $31(10-63)$ & $48(16-82)$ & $28(4-78)$ \\
\hline Turmalina & $13(1-41)$ & $9(3-19)$ & $12(3-24)$ & $15(1-41)$ & $12(1-23)$ \\
\hline Rutilo & $3(0-10)$ & $3(2-4)$ & $2(0-6)$ & $3(0-10)$ & $2(0-4)$ \\
\hline Apatita & $23(0-64)$ & $33(8-57)$ & $27(0-54)$ & $21(0-64)$ & $15(0-53)$ \\
\hline Granada & $16(0-91)$ & $31(2-77)$ & $16(0-46)$ & $5(0-40)$ & $34(0-91)$ \\
\hline Anatásio & $7(0-28)$ & $3(0-6)$ & $7(0-28)$ & $6(0-14)$ & $8(1-17)$ \\
\hline Titanita & $1(0-11)$ & $2(0-5)$ & $1(0-4)$ & $1(0-11)$ & $0(0-1)$ \\
\hline Monazita & $0(0-4)$ & $0(0-1)$ & $1(0-4)$ & $0(0-1)$ & $0(0-1)$ \\
\hline Sillimanita & $1(0-5)$ & $0(0-1)$ & $0(0-2)$ & $0(0-2)$ & $1(0-5)$ \\
\hline Cianita & $0(0-1)$ & ñ observada & $0(0-1)$ & ñ observada & ñ observada \\
\hline Epídoto & $0(0-2)$ & $0(0-2)$ & $0(0-2)$ & $0(0-2)$ & $\tilde{n}$ observada \\
\hline Estaurolita & $0(0-1)$ & $0(0-1)$ & ñ observada & ñ observada & ñ observada \\
\hline Hornblenda & $0(0-1)$ & $\tilde{n}$ observada & $\tilde{n}$ observada & $0(0-1)$ & $0(0-1)$ \\
\hline Zircão + Turmalina + Rutilo & $51(5-97)$ & $28(13-48)$ & $45(20-89)$ & $67(27-97)$ & $42(5-95)$ \\
\hline $\begin{array}{l}\text { Zircão }+ \text { Turmalina }+ \text { Rutilo }+ \\
\text { Apatita }+ \text { Granada }+ \text { Anatásio }\end{array}$ & $98(93-100)$ & $95(94-99)$ & $98(93-100)$ & $98(96-100)$ & $98(94-100)$ \\
\hline
\end{tabular}

Todas as unidades apresentam valores médios similares dos índices ZTR, ZTi, ZRi e ATi, mas com distinta variabilidade desses índices (figuras 13 e 14). O índice ZTR apresenta a maior diferença entre as médias das unidades, sendo 20 para a Formação Serra do Apertado e 40 para a Formação Pedra Pintada; e 28 e 27 para as formações Guarda Velha e Varzinha, respectivamente. O índice ATi apresenta a menor diferença, 79 para a Formação Guarda Velha e 83 para a Formação Serra do Apertado. Para o índice ZTi, as médias variam entre 62 para a Formação Guarda Velha e 73 para a Formação Pedra Pintada. Para o índice ZRi, as médias variam entre 81 para a Formação Guarda Velha e 92 para a Formação Pedra Pintada. Quando comparados por sistemas deposicionais, todos os 
índices apresentam valores maiores para as fácies eólicas em relação às fácies fluviais (Tabela 6).

Tabela 5: Estatísticas descritivas dos índices ZTR, ZTi, ZRi e ATi, separados por unidades estratigráficas.

\begin{tabular}{|c|l|r|r|r|r|r|r|r|r|}
\cline { 2 - 9 } \multicolumn{1}{c|}{} & \multicolumn{1}{c|}{ Formação } & N & Média & $\begin{array}{r}\text { Desvio } \\
\text { Padrão }\end{array}$ & Mínimo & $\mathbf{1}^{\circ}$ Quartil & Mediana & $3^{\circ}$ Quartil & Máximo \\
\hline \multirow{3}{*}{ ZTR } & Guarda Velha & 7 & 28.14 & 13.39 & 13.00 & 17.00 & 26.36 & 44.63 & 48.00 \\
& Varzinha & 5 & 27.60 & 6.69 & 20.00 & 21.00 & 28.00 & 34.00 & 36.00 \\
& Pedra Pintada & 8 & 40.45 & 8.92 & 27.00 & 34.25 & 40.00 & 47.94 & 53.00 \\
& Serra do Apertado & 4 & 20.75 & 12.04 & 5.00 & 8.25 & 23.00 & 31.00 & 32.00 \\
\hline \multirow{3}{*}{ ZTi } & Guarda Velha & 7 & 62.13 & 23.05 & 26.26 & 36.00 & 65.00 & 80.00 & 89.00 \\
& Varzinha & 11 & 67.70 & 20.32 & 25.00 & 52.22 & 70.00 & 85.00 & 94.00 \\
& Pedra Pintada & 19 & 73.90 & 13.88 & 37.00 & 65.52 & 76.00 & 85.23 & 93.00 \\
& Serra do Apertado & 7 & 68.26 & 10.87 & 54.00 & 62.00 & 64.94 & 75.00 & 88.00 \\
\hline \multirow{3}{*}{ ZRi } & Guarda Velha & 7 & 81.03 & 13.35 & 66.67 & 67.00 & 75.56 & 95.00 & 98.00 \\
& Varzinha & 11 & 90.06 & 12.98 & 54.00 & 88.00 & 94.00 & 98.00 & 99.00 \\
& Pedra Pintada & 19 & 92.20 & 4.84 & 82.61 & 87.64 & 94.03 & 96.00 & 99.00 \\
& Serra do Apertado & 7 & 87.31 & 9.37 & 74.00 & 75.00 & 90.91 & 95.00 & 96.23 \\
\hline \multirow{2}{*}{ ATi } & Guarda Velha & 7 & 79.34 & 7.71 & 66.40 & 75.00 & 79.00 & 86.00 & 89.00 \\
& Varzinha & 5 & 82.15 & 12.07 & 65.00 & 69.50 & 88.52 & 91.62 & 92.68 \\
& Pedra Pintada & 8 & 81.79 & 9.20 & 65.45 & 76.12 & 82.99 & 88.57 & 95.45 \\
& Serra do Apertado & 4 & 83.75 & 6.85 & 80.00 & 80.00 & 80.50 & 90.75 & 94.00 \\
\hline
\end{tabular}

Tabela 6: Estatísticas descritivas dos índices ZTR, ZTi, ZRi e ATi, categorizados por sistema deposicional.

\begin{tabular}{|c|l|c|r|r|r|r|r|r|r|}
\cline { 2 - 10 } \multicolumn{1}{c|}{} & \multicolumn{1}{|c|}{ Fácies } & \multicolumn{1}{c|}{ N } & \multicolumn{1}{c|}{ Média } & $\begin{array}{c}\text { Desvio } \\
\text { Padrão }\end{array}$ & Mínimo & $\mathbf{1}^{\circ}$ Quartil & Mediana & $\mathbf{3}^{\circ}$ Quartil & Máximo \\
\hline \multirow{2}{*}{ ZTR } & Eólico & 6 & 40.43 & 9.97 & 27.00 & 32.25 & 40.00 & 49.69 & 53.00 \\
& Fluvial & 18 & 27.72 & 11.56 & 5.00 & 19.50 & 27.50 & 35.35 & 38.00 \\
\hline \multirow{2}{*}{$\mathbf{Z T i}$} & Eólico & 13 & 75.73 & 9.83 & 55.74 & 70.47 & 76.00 & 84.11 & 91.00 \\
& Fluvial & 31 & 67.00 & 18.65 & 25.00 & 58.00 & 69.86 & 83.00 & 94.00 \\
\hline \multirow{2}{*}{ ZRi } & Eólico & 13 & 92.73 & 4.06 & 83.82 & 90.24 & 94.03 & 96.00 & 97.00 \\
& Fluvial & 31 & 87.59 & 11.45 & 54.00 & 82.61 & 91.00 & 96.23 & 99.00 \\
\hline \multirow{2}{*}{$\mathbf{A T i}$} & Eólico & 6 & 85.40 & 6.62 & 76.00 & 81.23 & 84.17 & 91.11 & 95.45 \\
& Fluvial & 18 & 80.17 & 9.03 & 65.00 & 74.75 & 80.00 & 88.64 & 94.00 \\
\hline
\end{tabular}

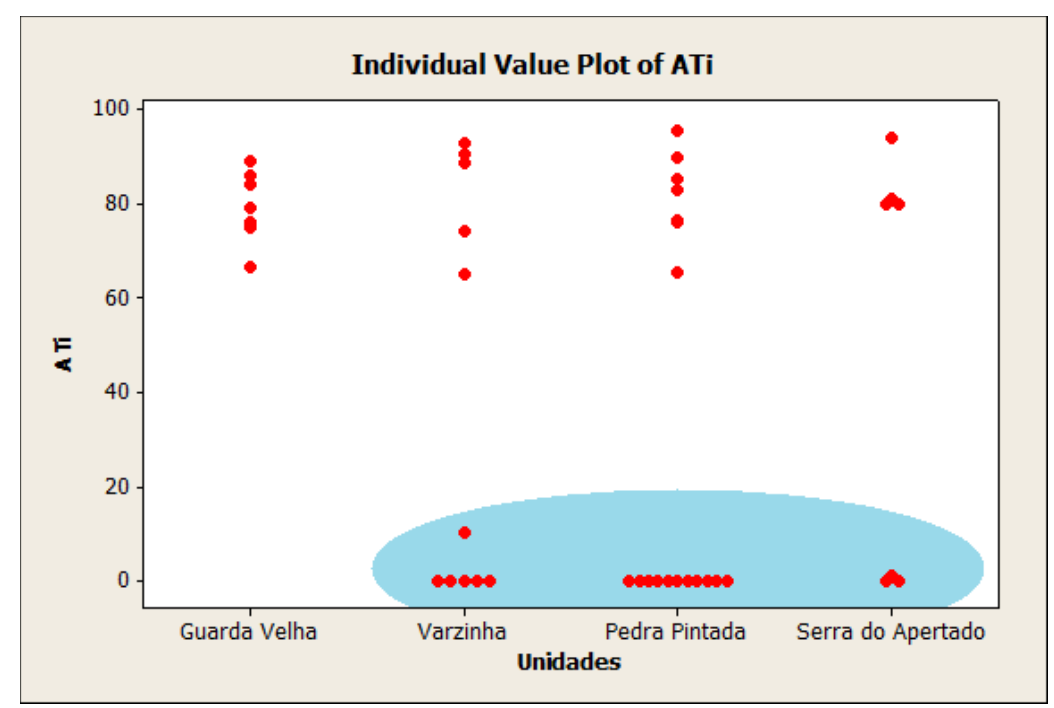

Figura 12: Valores do índice ATi para as amostras das unidades do Grupo Guaritas. Amostras com baixo índice ATi são destacadas. 


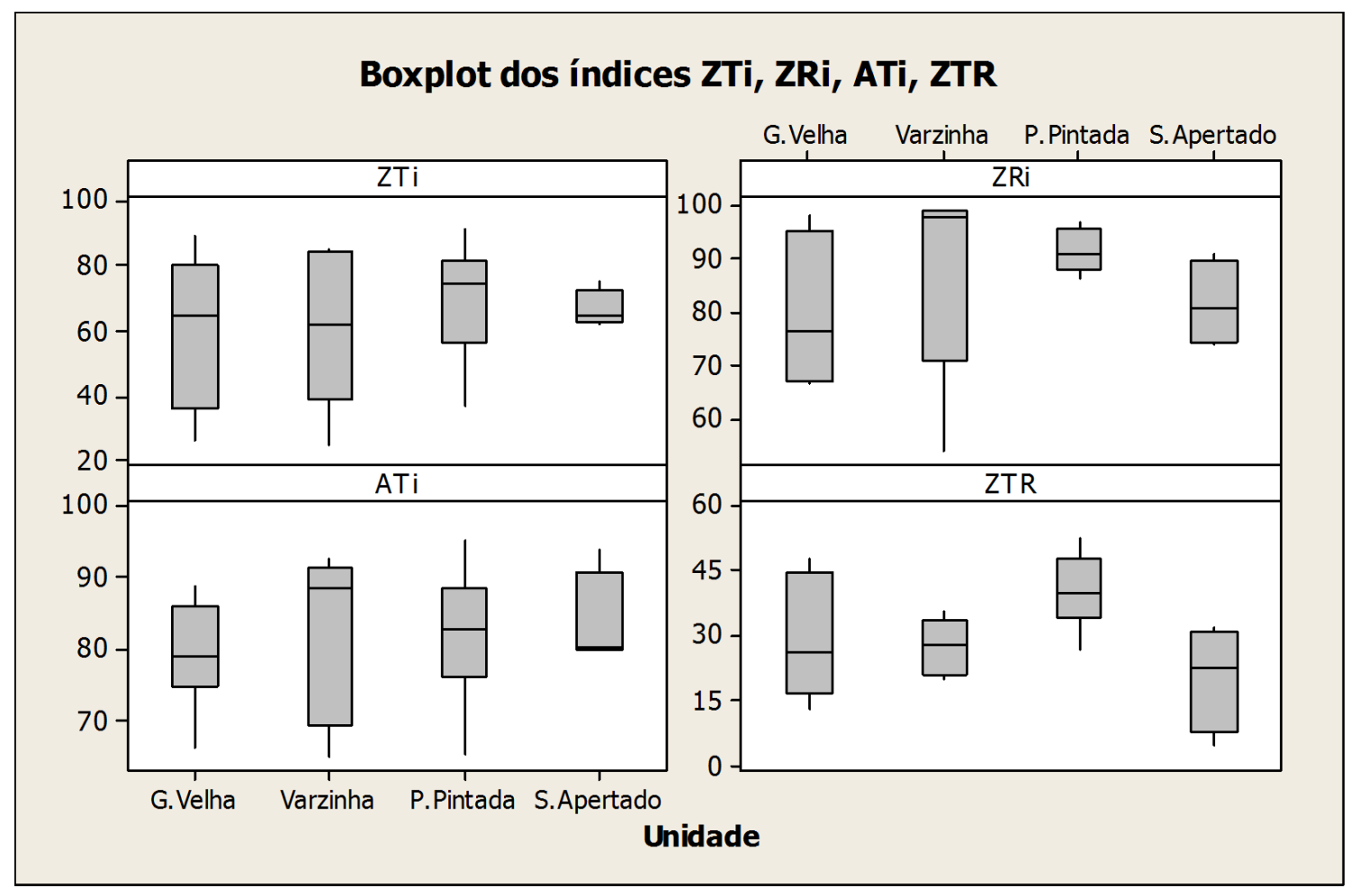

Figura 13: Boxplot dos índices ZTi, ZRi, ATi e ZTR, separados por unidade estratigráfica. O boxplot é constituído de uma caixa limitada pelos $1^{\circ}$ e $3^{\circ}$ quartis (Q1 e Q3) e dividida pela mediana, possui duas retas, denominadas bigodes, cujos comprimentos respondem à Q1-1,5(Q3-Q1) ou valor mínimo e Q3+1,5(Q3-Q1) ou valor máximo. Os valores fora desse intervalo são denominados anômalos (outliers) e representados por asteriscos.

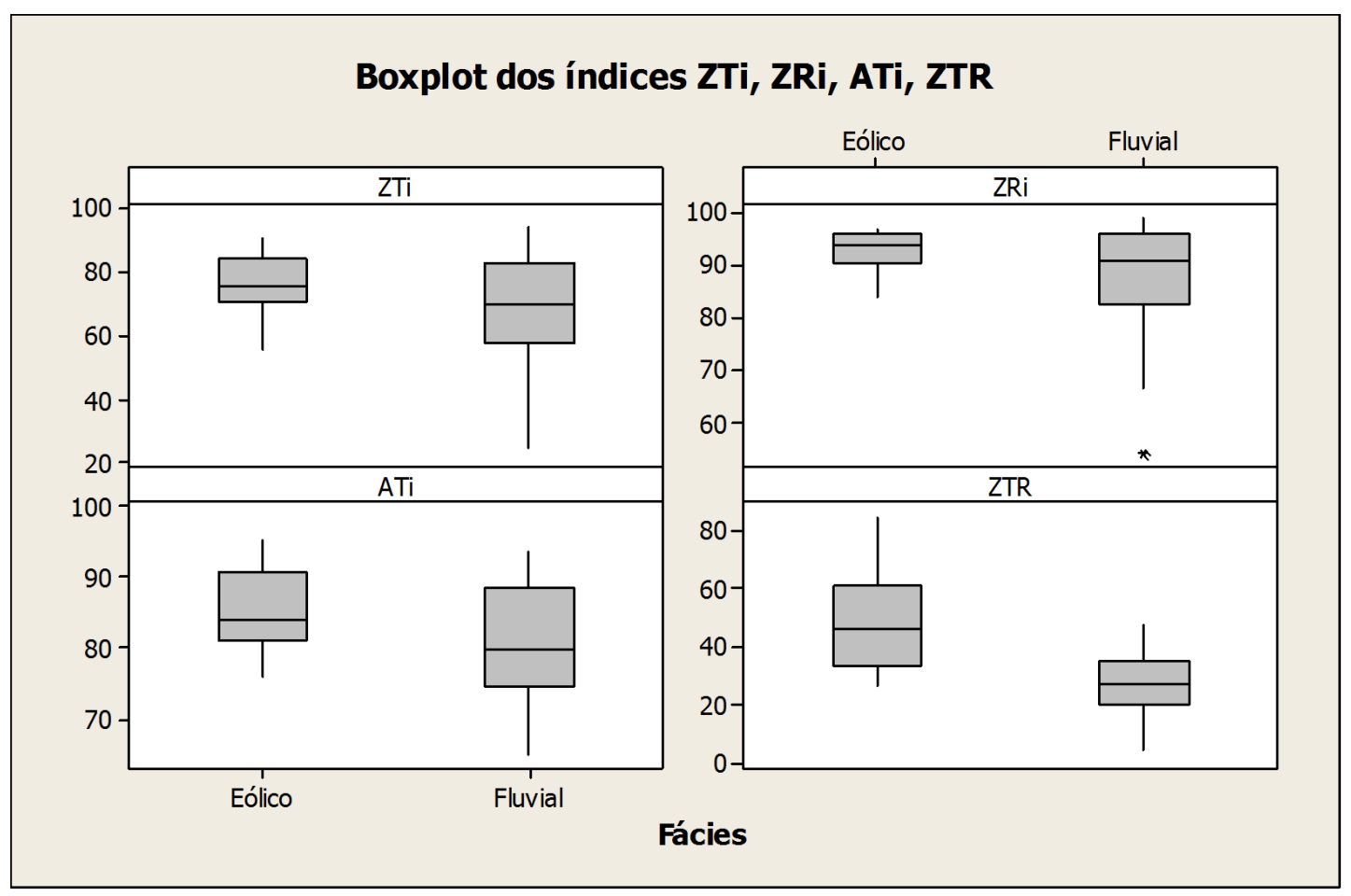

Figura 14: Boxplot dos índices ZTi, ZRi, ATi e ZTR, separados por sistema deposicional. 


\section{V.4.Sensibilidade LOE do quartzo}

Foram analisadas as curvas LOE resultantes de cada grão de quartzo (Figura 5C). Estas curvas são apresentadas em gráficos que relacionam tempo de estimulação (canal) com o número de fótons emitidos durante a excitação do grão por laser verde (contagens).

Estatísticas descritivas foram calculadas para as medidas LOE (sensibilidade total, sensibilidade dos componentes rápido, médio e lento, porcentagens dos componentes e razões rápido/lento, rápido/médio e médio/lento), as quais também foram categorizadas por unidades estratigráficas e fácies (tabelas 7 e 8). As figuras 15, 16 e 17 apresentam os gráficos boxplot para as variáveis LOE. A Figura 18 apresenta os gráficos ternários entre as porcentagens dos componentes rápido (1-10), médio (10-30) e lento (30-50).

Nota-se que as formações Guarda Velha e Varzinha apresentam maior média para sensibilidade LOE total em relação as demais unidades. No entanto, destacam-se desvios padrão elevados para todas as unidades. Também apresentam maior mediana e maior distância entre quartis para a sensibilidade total. Para todas as unidades, a \%lento (43-46) domina a curva de sensibilidade total, seguida pela \%médio (37-38), enquanto a \%rápido (15-18) é subordinada. Quanto à caracterização por fácies (Tabela 8), a fácies eólica apresenta menor média e mediana para sensibilidade LOE total em relação à fácies fluvial, mas não apresentam diferenças significativas entre suas componentes.

Tabela 7: Estatísticas descritivas da intensidade LOE total (Integral (1-50)) e dos componentes rápido, médio e lento, categorizados por unidades estratigráficas. A intensidade LOE total é representada em contagens de

fótons.

\begin{tabular}{|c|c|c|c|c|c|c|c|c|c|}
\hline & Formação & $\mathrm{N}$ & Média & $\begin{array}{l}\text { Desvio } \\
\text { Padrão }\end{array}$ & $1^{\circ}$ Quartil & Mediana & $3^{\circ}$ Quartil & Mínimo & Máximo \\
\hline \multirow{4}{*}{ Integral (1-50) } & Guarda Velha & 164 & 3295,12 & 4791,70 & 1580,50 & 2196,50 & 2897,25 & 916,00 & 35590,00 \\
\hline & Varzinha & 206 & 3655,41 & 3358,77 & 1877,00 & 2808,50 & 4081,50 & 704,00 & 26088,00 \\
\hline & Pedra Pintada & 182 & 2271,69 & 3546,27 & 1214,25 & 1599,50 & 2224,25 & 667,00 & 33312,00 \\
\hline & Serra do Apertado & 150 & 2457,59 & 3848,04 & 1229,50 & 1673,00 & 2185,00 & 680,00 & 37132,00 \\
\hline \multirow{4}{*}{ \%rápido (1-10) } & Guarda Velha & 164 & 18,44 & 7,79 & 13,80 & 16,87 & 20,22 & 9,45 & 61,59 \\
\hline & Varzinha & 206 & 15,67 & 5,32 & 11,66 & 14,59 & 18,83 & 6,87 & 38,57 \\
\hline & Pedra Pintada & 182 & 18,92 & 6,63 & 14,34 & 17,80 & 20,82 & 7,31 & 41,57 \\
\hline & Serra do Apertado & 150 & 17,45 & 5,58 & 14,12 & 16,93 & 19,17 & 8,17 & 51,53 \\
\hline \multirow{4}{*}{$\%$ médio $(10-30)$} & Guarda Velha & 164 & 37,55 & 3,14 & 36,03 & 37,46 & 39,32 & 25,46 & 50,49 \\
\hline & Varzinha & 206 & 38,24 & 2,55 & 36,59 & 38,02 & 39,76 & 29,94 & 51,83 \\
\hline & Pedra Pintada & 182 & 37,41 & 2,93 & 36,05 & 37,40 & 39,04 & 27,05 & 45,97 \\
\hline & Serra do Apertado & 150 & 37,94 & 2,18 & 36,52 & 37,86 & 39,15 & 31,89 & 43,87 \\
\hline \multirow{4}{*}{ \%lento $(30-50)$} & Guarda Velha & 164 & 44,02 & 6,72 & 41,37 & 44,86 & 48,50 & 12,94 & 54,61 \\
\hline & Varzinha & 206 & 46,09 & 5,58 & 42,32 & 47,07 & 50,38 & 27,73 & 55,67 \\
\hline & Pedra Pintada & 182 & 43,68 & 6,10 & 40,11 & 44,07 & 48,09 & 21,69 & 56,38 \\
\hline & Serra do Apertado & 150 & 44,62 & 5,74 & 41,53 & 44,96 & 48,76 & 16,58 & 56,47 \\
\hline
\end{tabular}


Tabela 8: Estatísticas descritivas da intensidade LOE total e das porcentagens dos componentes rápido, médio e lento, categorizadas por sistema deposicional.

\begin{tabular}{|c|l|c|r|r|r|r|r|r|r|}
\cline { 2 - 10 } & Fácies & N & \multicolumn{1}{c|}{ Média } & $\begin{array}{c}\text { Desvio } \\
\text { Padrão }\end{array}$ & Mínimo & 1 $^{\circ}$ Quartil & Mediana & $3^{\circ}$ Quartil & Máximo \\
\hline \multirow{2}{*}{ Integral (1-50) } & Eólico & 182 & 2271,69 & 3546,27 & 1214,25 & 1599,50 & 2224,25 & 667,00 & 33312,00 \\
& Fluvial & 520 & 3196,26 & 4020,27 & 1547,50 & 2179,50 & 3222,75 & 680,00 & 37132,00 \\
\hline \multirow{2}{*}{$\%$ rápido (1-10) } & Eólico & 182 & 18,92 & 6,63 & 14,34 & 17,80 & 20,82 & 7,31 & 41,57 \\
& Fluvial & 520 & 17,05 & 6,37 & 13,10 & 15,76 & 19,37 & 6,87 & 61,59 \\
\hline \multirow{2}{*}{$\%$ médio (10-30) } & Eólico & 182 & 37,41 & 2,93 & 36,05 & 37,40 & 39,04 & 27,05 & 45,97 \\
& Fluvial & 520 & 37,93 & 2,67 & 36,47 & 37,86 & 39,42 & 25,46 & 51,83 \\
\hline \multirow{2}{*}{$\%$ \%lento (30-50) } & Eólico & 182 & 43,68 & 6,10 & 40,11 & 44,07 & 48,09 & 21,69 & 56,38 \\
& Fluvial & 520 & 45,01 & 6,06 & 41,86 & 45,56 & 49,36 & 12,94 & 56,47 \\
\hline
\end{tabular}
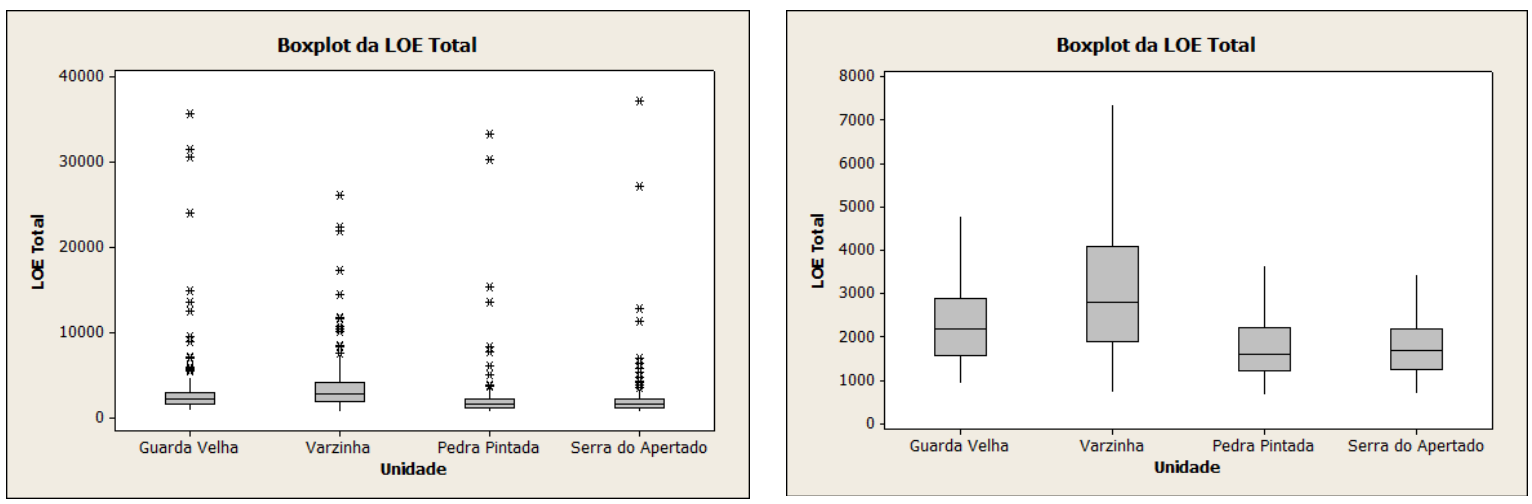

Figura 15: Gráficos boxplot para as medidas de sensibilidade LOE total (Integral (1-50)), com e sem valores anômalos (outliers), separadas por unidade estratigráfica. Sensibilidade LOE em contagens de fótons.

\section{Boxplot dos componentes rápido, médio e lento}
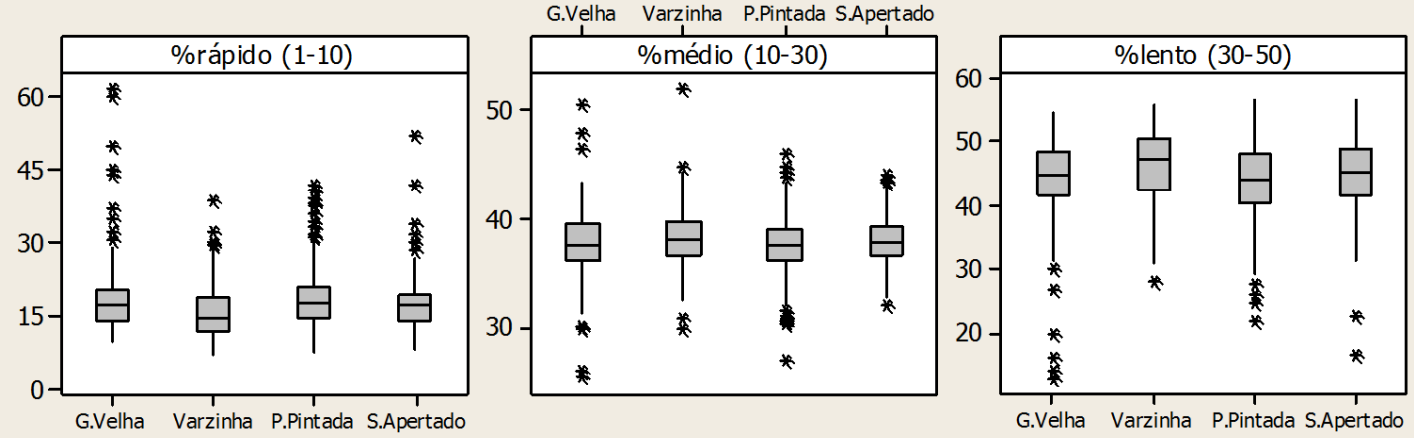

Unidade

Figura 16: Gŕaficos Boxplot para as porcentagens dos componentes (rápido, médio e lento) de sensibilidade LOE, separados por unidade estratigráfica. 


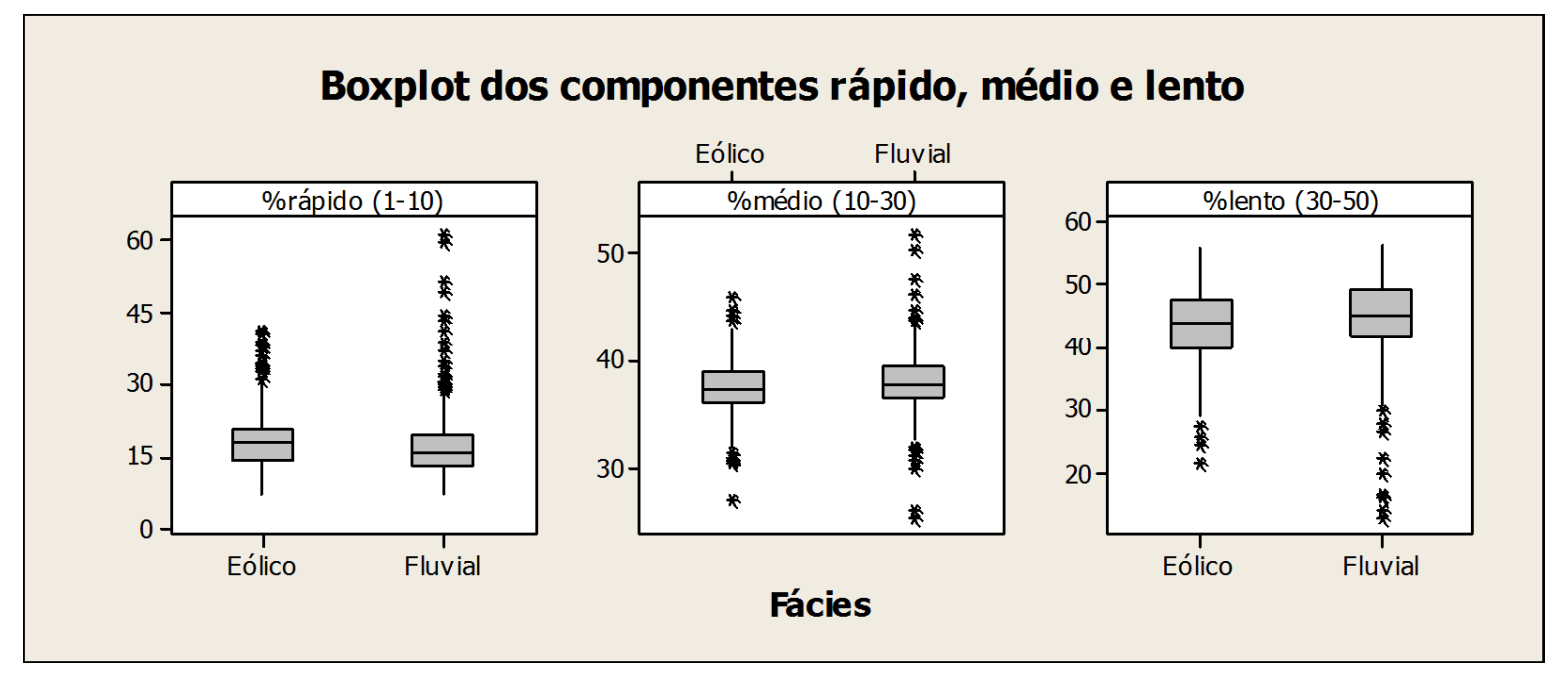

Figura 17: Gŕaficos Boxplot para as porcentagens dos componentes (rápido, médio e lento) de sensibilidade LOE, separados por sistema deposicional.

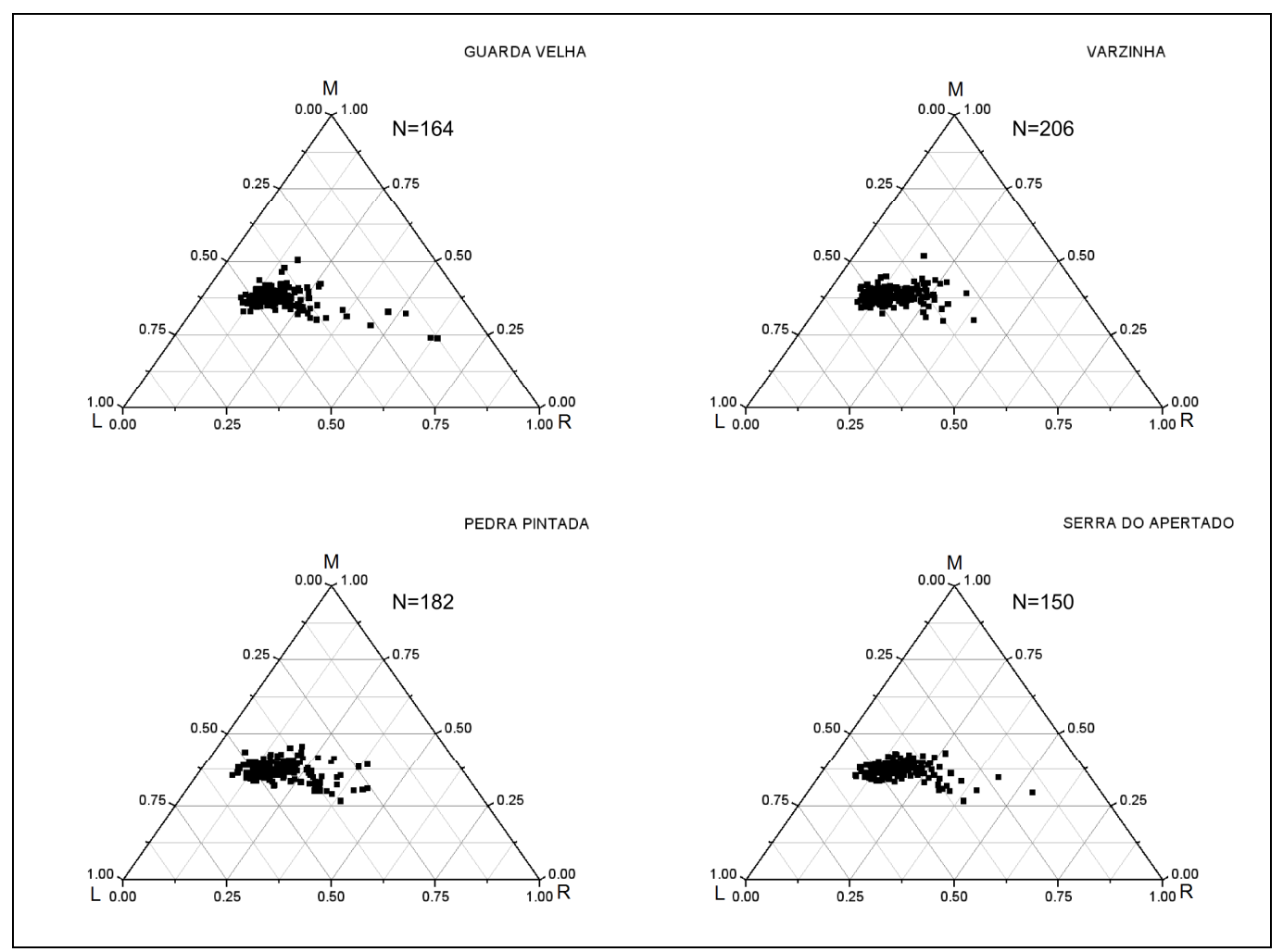

Figura 18: Gráficos ternários das porcentagens dos componentes rápido $(\mathrm{R})$, médio $(\mathrm{M})$ e lento $(\mathrm{L})$, separados por unidades estratigráficas.

Os diagramas ternários das formações Guarda Velha, Varzinha, Pedra Pintada e Serra do Apertado apresentam distribuições muito semelhantes das proporções dos componentes rápido, médio e lento, com os pontos concentrados distante do vértice 
\%rápido e entre os vértices \%médio e \% lento. Os dados da Formação Guarda Velha possuem maior distribuição em direção ao componente \%rápido, relativamente às outras formações. A Formação Serra do Apertado aparenta ter distribuição dos pontos intermediária entre a Formação Guarda Velha e as formações Varzinha e Pedra Pintada. Estas últimas apresentam poucas diferenças entre si, não sendo possível distingui-las pelas proporções dos componentes LOE rápido, médio e lento. 


\section{DISCUSSÃO}

\section{VI.1.Rochas-fontes}

As rochas do Grupo Guaritas correspondem a arcóseos, subarcóseos e sublitoarenitos (sensu Folk 1968). Esses resultados são compatíveis com os apresentados por De Ros et al. (1994), que classificam estas rochas como arcóseos líticos e litoarenitos arcoseanos (sensu Folk 1968). Análises modais realizadas por De Ros et al. (1994) indicaram que os fragmentos líticos dos arenitos do Grupo Guaritas abrangem em média $5,5 \%$ de rochas vulcânicas, $4,3 \%$ de rochas metamórficas e $0,1 \%$ de rochas sedimentares. Com base na variação espacial destes resultados, estes autores interpretam que a principal área-fonte dos sedimentos do Grupo Guaritas estaria localizada a oeste da Bacia do Camaquã e seria composta por rochas plutônicas (granitos), vulcânicas (riolitos, tufos ácidos e ignimbritos) e metamórficas (ardósias, filitos, xistos, metavulcânicas, metassedimentares e gnaisses). No entanto, os fragmentos líticos das rochas de granulação grossa, tais como as rochas plutônicas, são sub-representados nos arenitos. A grande quantidade de feldspatos é concordante com a abundância de apatita na assembléia de minerais pesados, encontrada neste estudo, pois ambos minerais são instáveis em condições de intemperismo úmido. Isto sugere ambiente árido e/ou elevadas taxas de deposição ou ainda intemperismo químico pouco efetivo devido à ausência de vegetação para os sedimentos do Grupo Guaritas. Os dados de petrografia de seções delgada indicam, segundo o diagrama de Dickinson (1985), deposição em ambiente tectônico de bloco continental soerguido a transicional. Esses resultados são compatíveis com os apresentados por De Ros et al. (1994). A cimentação carbonática amplamente distribuída nos arenitos analisados implicaria em fluidos diagenéticos alcalinos.

O embasamento da Bacia do Camaquã é formado predominantemente por rochas metamórficas (xistos, filitos e gnaisses) das unidades Dom Feliciano e Rio Vacacaí e por rochas graníticas neoproterozóicas (Fragoso-Cesar 1980, 1991). Os minerais pesados identificados nas unidades do Grupo Guaritas foram: zircão, apatita, turmalina, anatásio, granada, rutilo, titanita, monazita, sillimanita, estaurolita, epídoto e cianita. A presença de 
estaurolita, sillimanita e cianita indicaria rochas metamórficas aluminosas como fonte dos sedimentos do Grupo Guaritas. A baixa proporção destes minerais permite supor que as rochas metamórficas atuaram como fonte subordinada. Entretanto, essa baixa proporção pode ser resultado da dissolução diagenética. Porém, a pequena quantidade de grãos de rutilo, mineral resistente à dissolução e que é mais freqüente em rochas metamórficas, especialmente em rochas de alto grau (Mange \& Maurer 1992), indicaria pequena contribuição de sedimentos derivados de rochas metamórficas. Apatita, turmalina, granada, epídoto, titanita e monazita ocorrem tanto em rochas ígneas quanto em rochas metamórficas (Deer et al. 1992; Klein 2002). Fluorapatita (variedade mais comum de apatita) é mineral acessório típico de rochas graníticas enquanto que epídoto é mais freqüente em rochas ígneas básicas e turmalina predomina em rochas ígneas ácidas (Mange \& Maurer 1992). Zircão é mineral acessório ubíquo em rochas ígneas ácidas. Porém, é freqüente em rochas metamórficas e sedimentares, onde está presente como cristal herdado. A presença de grãos de zircão com arredondamento elevado, sem evidências de corrosão metamórfica ou magmática, seria indicativa de rocha-fonte sedimentar. A abundância de grãos de zircão (até 82\%), apatita (até 64\%) e granada (até 91\%) nos sedimentos do Grupo Guaritas, associada à baixa proporção de minerais tipicamente metamórficos (até 5\%), permite interpretar área-fonte dominada por rochas ígneas graníticas. Parte da granada pode ser proveniente dos xistos encontrados no Alto de Caçapava, a oeste da bacia. Os granitos neoproterozóicos, os quais abrangem os granitos Caçapava do Sul (Nardi \& Bitencourt 1989), Lavras do Sul (Nardi \& Lima 2000), Ramada (Naime \& Nardi 1991), São Sepé (Mattos et al. 2004), além do batólito Pelotas (FragosoCesar et al.1986, Phillipp \& Machado 2001), têm como minerais acessórios zircão, apatita, turmalina, granada, titanita, anfibólio, epídoto e fluorita. Segundo Morton (1985), anfibólio, epídoto e titanita são minerais instáveis em condições diagenéticas de grande profundidade (fluidos alcalinos), enquanto que granada e apatita são estáveis e turmalina e zircão são ultraestáveis. Grãos euédricos de anatásio (até $28 \%$ ) podem ser oriundos da transformação diagenética de grãos de titanita. Assim, a associação mineralógica zircãoapatita-turmalina-granada, que domina a assembléia de minerais pesados dos sedimentos analisados, indicaria que os granitos neoproterozóicos foram as principais rochas-fonte dos sedimentos do Grupo Guaritas. Isto poderia indicar maior área de exposição e/ou maior declividade das áreas com rochas ígneas ácidas aflorantes durante o fechamento da Bacia do Camaquã.

A pequena variação dos valores do índice ZRi (81-91) aponta para a manutenção da 
configuração das áreas-fonte e do sistema de captação dos sedimentos. O índice ATi (7985) não apresentou diferenças significativas entre as unidades. No entanto, indicou amostras que apresentavam alteração pós-deposicional da assembléia de minerais pesados, as quais foram excluídas das análises estatísticas. Assim, todas as unidades apresentam valores do índice ZRi e assembléias de minerais pesados semelhantes, permitindo interpretar que grande parte da configuração da área-fonte se manteve similar durante toda a deposição dos sedimentos do Grupo Guaritas. Porém, cada unidade estratigráfica representaria áreas de captação levemente distintas.

\section{VI.2.Retrabalhamento e aporte sedimentar}

Os valores do índice ZTR sugerem maior retrabalhamento dos sedimentos da Formação Pedra Pintada (27-97) em relação aos das formações Guarda Velha (13-48), Varzinha (20-89) e Serra do Apertado (05-95). No entanto, a interpretação do índice ZTR é complicada devido à sua elevada sensibilidade à dissolução pós-deposicional. Os valores similares do índice ZTi (61-69), pouco sensível à alterações pós-deposicionais, apontam sedimentos com grau de retrabalhamento semelhante para as unidades do Grupo Guaritas.

Os valores das intensidades totais LOE do quartzo das unidades Guarda Velha, Varzinha, Pedra Pintada e Serra do Apertado apresentam medianas reduzidas (1599 a 2808 contagens) se comparadas às medianas de sedimentos de elevado grau de retrabalhamento obtidos por Sawakuchi et al. (2010) em areias costeiras (3716 a 6191 contagens). Isto indicaria que os sedimentos de todas as unidades do Grupo Guaritas têm grau de retrabalhamento relativamente reduzido (Figura 18), porém superior ao retrabalhamento de areias fluviais transportadas por até dezenas de quilômetros $(\sim 40 \mathrm{~km})$ em rio de fluxo regular (medianas de 805 a 1165 contagens). As formações Guarda Velha e Varzinha apresentam valores de sensibilidade total maiores que os observados nas formações Pedra Pintada e Serra do Apertado, indicando maior grau de retrabalhamento que essas últimas formações. As proporções entre os valores dos componentes rápido (1-10), médio (10-30) e lento (30-50) indicam maior variabilidade na Formação Guarda Velha em relação às demais unidades, o que representa grãos com diferentes graus de retrabalhamento sedimentar. A Formação Serra do Apertado apresenta resultados intermediários entre os da Formação Guarda Velha e os das formações Varzinha e Pedra Pintada. Esses resultados indicam que as formações Guarda Velha e Serra do Apertado possuíam sistemas deposicionais com maior retrabalhamento sedimentar, em relação aos sistemas das formações Varzinha e Pedra Pintada, que sofreram reduzido retrabalhamento sedimentar. 
Os componentes médio e lento dos diagramas ternários apresentam grande semelhança com os diagramas de Sawakuchi et al. (2010), enquanto que o componente rápido mantém semelhança apenas com os diagramas de sedimentos fluviais (transporte de 1 a $40 \mathrm{~km}$ ), mais proximais e menos retrabalhados (Figura 19), em relação aos sedimentos policíclicos costeiros (eólico e praial).

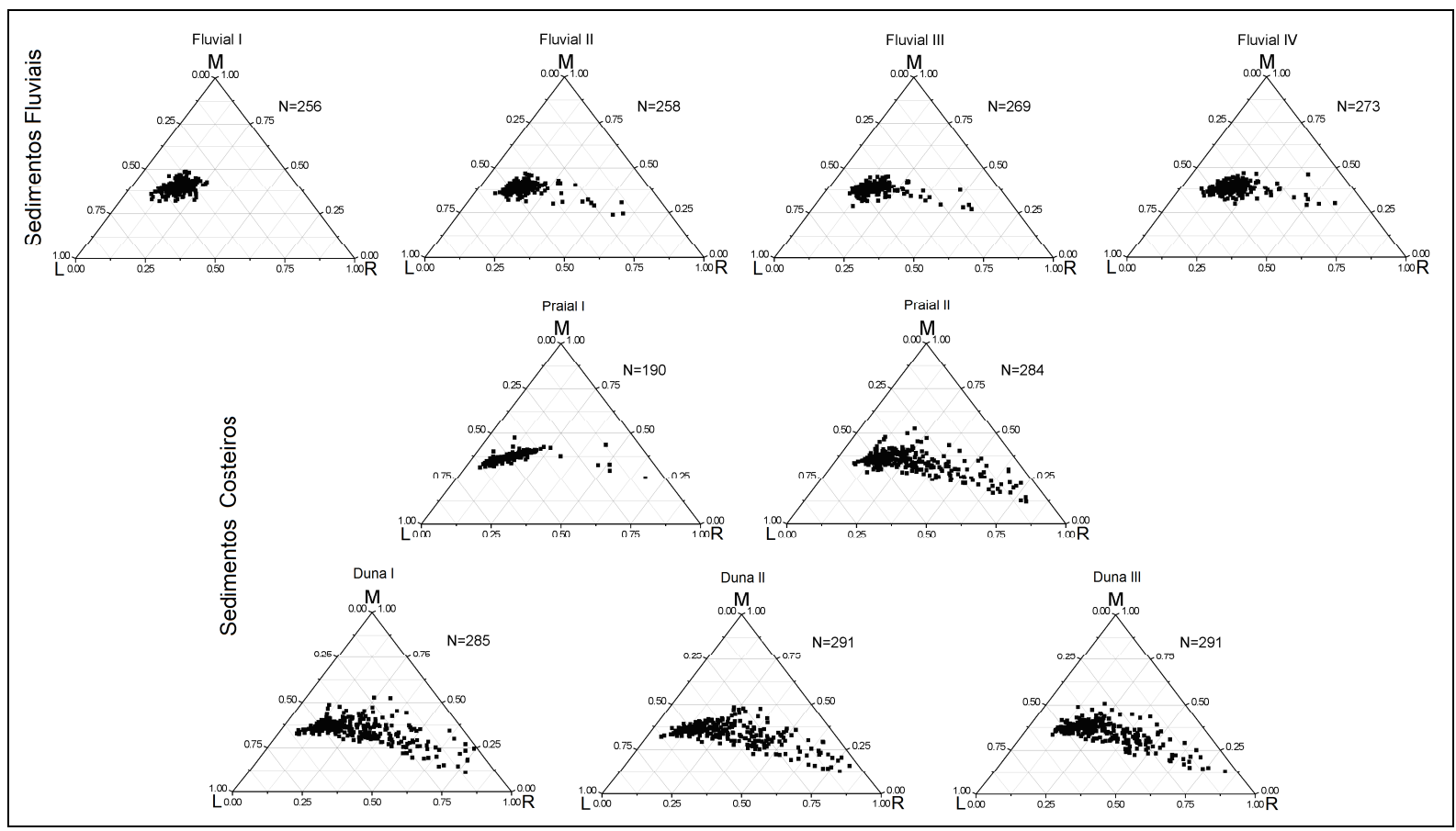

Figura 19: Gráficos ternários das porcentagens dos componentes LOE (rápido, médio e lento) medidos por Sawakuchi et al. (2010) em sedimentos fluviais e costeiros (dunares e praiais), os quais apresentam graus de retrabalhamento baixo (monocíclico) e elevado (policíclico), respectivamente.

A partir desses resultados é possível interpretar como os sistemas deposicionais representados nas unidades do Grupo Guaritas interagiam entre si (Figura 20). A Formação Guarda Velha, mais basal, apresenta sensibilidade total LOE alta e maior variabilidade em seus componentes, que pode ser interpretada como a unidade com maior retrabalhamento (mais ciclos de erosão-deposição) e que serviu de fonte para a Formação Varzinha, que possui grãos mais retrabalhados. A Formação Varzinha apresenta a maior sensibilidade total LOE (e maior distância interquartis) e a menor variabilidade de seus componentes entre as unidades. A primeira característica pode ser interpretada como devido ao retrabalhamento herdado da Formação Guarda Velha e por possuir sistema deposicional semelhante ao desta (fluvio-aluvial). Já a segunda, por ter grande contribuição de sedimentos pouco retrabalhados possivelmente derivados de fonte primária mais proximal. 
A Formação Pedra Pintada apresenta sensibilidades total LOE e variabilidade baixas o que indicaria pouca contribuição sedimentar das unidades anteriores, pouco retrabalhamento e rápido soterramento. A Formação Serra do Apertado apresenta sensibilidade total LOE baixa indicando pouco retrabalhamento e pouca contribuição das formações Guarda Velha e Varzinha, e variabilidade relativamente alta, que corrobora a assinatura apresentada pelo sistema deposicional da Formação Guarda Velha. No caso, ambas formações são depósitos associados a rios troncos (sistema fluvial axial) e apresentaram assinaturas semelhantes quanto os componentes LOE.

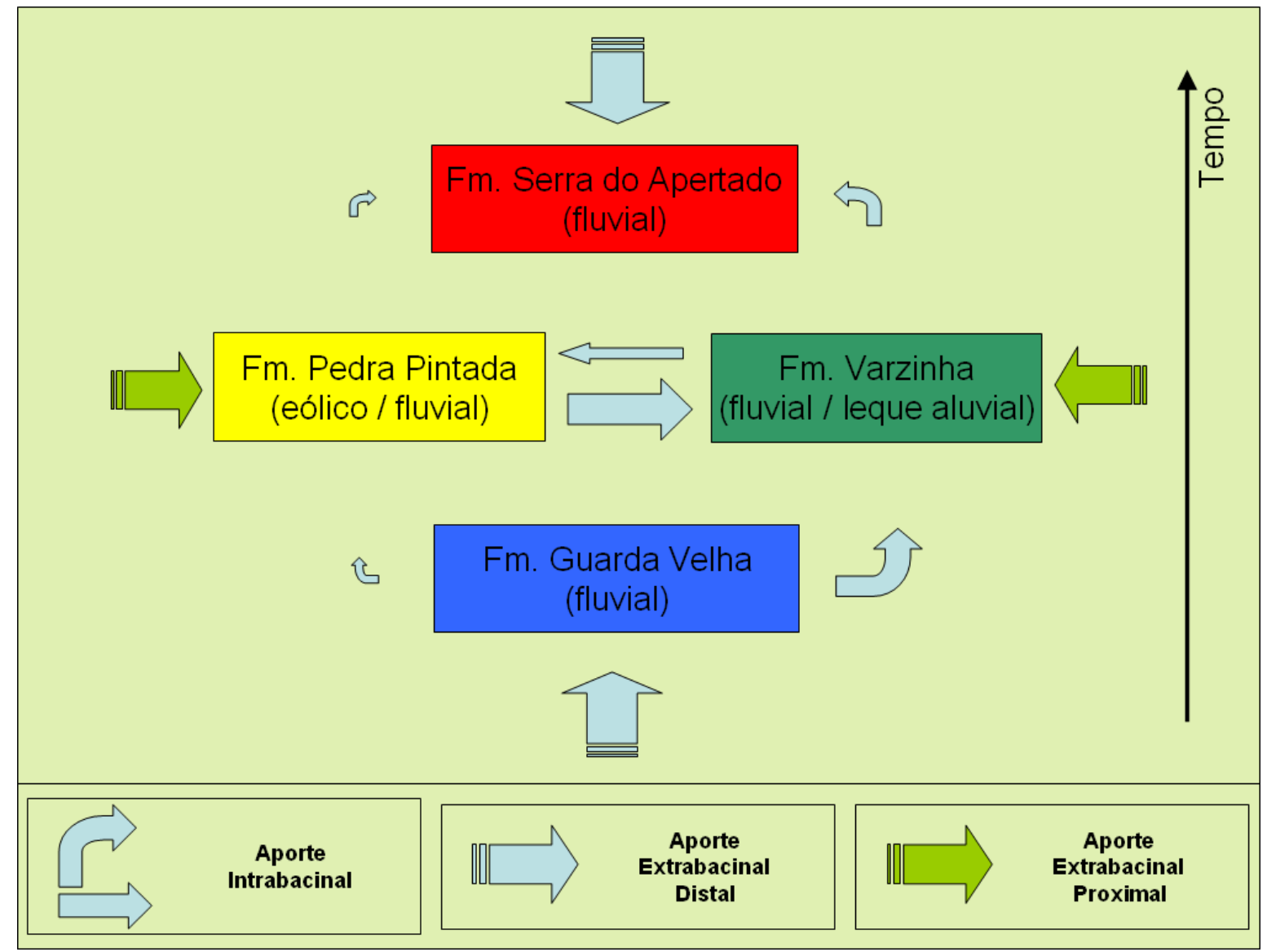

Figura 20: Modelo esquemático das interações entre os sistemas deposicionais do Grupo Guaritas. Setas maiores correspondem a aportes maiores.

Os resultados de proveniência obtidos neste estudo são compatíveis com as idéias propostas por De Ros et al. (1994) de que a área-fonte seria predominantemente adjacente a bacia e que o seu soterramento foi rápido. Os dados de luminescência corroboram o modelo proposto por Almeida et al. (2009), que indica que os sistemas deposicionais das formações Varzinha e Pedra Pintada interagiam entre si. Almeida et al. (2009) propõem ainda que as formações Guarda Velha e Serra do Apertado representariam sistemas fluviais 
axiais à bacia que transportavam sedimentos mais distais. Essas unidades apresentaram sedimentos com maior sensibilidade LOE, indicando maior retrabalhamento sedimentar. Esse maior grau de retrabalhamento é compatível com o modelo de rios troncos e proveniência distal. 


\section{CONCLUSÕES}

As análises de minerais pesados sugerem que os sedimentos do Grupo Guaritas são derivados principalmente de rochas ígneas ácidas (granitos neoproterozóicos) e subordinadamente de rochas metamórficas e sedimentares. A similaridade do índice ZRi aponta manutenção da configuração litológica da área-fonte durante a sedimentação das unidades estudadas, onde rochas graníticas dominariam a área de produção e captação de sedimentos.

A abundância de apatita indica deposição em ambiente árido e/ou soterramento rápido, seguida de intensa dissolução diagenética dos minerais instáveis sob condições alcalinas. $\mathrm{O}$ soterramento rápido é compatível com o baixo retrabalhamento sedimentar interpretado a partir da sensibilidade LOE. A sensibilidade LOE do quartzo apresenta diferenças entre as formações Guarda Velha - Serra do Apertado e Varzinha - Pedra Pintada. A Formação Guarda Velha apresentaria maior contribuição de sedimentos mais distais e mais retrabalhados.

Apesar de os dados de sensibilidade LOE serem referentes a uma grande quantidade de grãos (cerca de 700), estes representam apenas quatro pontos distribuídos por toda a bacia, desse modo esses resultados apresentam caráter exploratório. No entanto, aliado aos métodos clássicos de proveniência, esses resultados aparentam ser consistentes o que torna o uso dessa ferramenta bastante promissor. A sensibilidade LOE do quartzo permite avaliar o grau de retrabalhamento de unidades sedimentares e aferir a proveniência também em sedimentos antigos (Cambriano), já que até então só haviam trabalhos sobre sedimentos recentes. Este trabalho é pioneiro e permitiu confirmar que a sensibilidade LOE do quartzo independe da idade do sedimento/rocha. 


\section{VII.REFERÊNCIAS BIBLIOGRÁFICAS}

ALMEIDA, R.P. de 2005. Tectônica e Sedimentação do Ediacariano ao Ordoviciano: Exemplos do Supergrupo Camaquã (RS) e do Grupo Caacupé (Paraguai Oriental). Tese de Doutoramento, Instituto de Geociências, Universidade de São Paulo.

ALMEIDA, R.P.; JANIKIAN, L.; FRAGOSO-CESAR, A.R.S.; MARCONATO, A. 2009. Evolution of a rift basin dominated by subaerial deposits: the Guaritas Rift, Early Cambrian, Southern Brazil. Sedimentary Geology, 217(1-4): 30-51.

ALMEIDA, R.P.; JANIKIAN, L.; FRAGOSO-CESAR, A.R.S.; FAMBRINI, G.L. 2010. The Ediacaran to Cambrian rift system of Southeastern South America: tectonic implications. The Journal of Geology, 118:154-161.

ANDERTON, R. 1985. Clastic facies models and facies analysis. In: Brenchley, P.J. \& Williams, B.P. eds. Recent Developments and Applied Aspects. Oxford, The Geol. Soc., Blackwell Scientific Publ.: 31-47.

BECKER, R. \& FERNANDES, L.A.D. 1982. Caracterização faciológica de uma sequência vulcano-sedimentar eo-paleozóica na Folha Passo do Tigre (RS). Acta Geologica Leopoldensia, 6(13):287-322.

BROOKFIELD, M.E. 1992. Eolian systems. In R. G. Walker and N. P. James (eds.) Facies models: response to sea-level change. Geological Association of Canada, Geotext 1. p. 143-156.

COLLINSON, J.D. 1996. Alluvial Sediments. In H. G. Reading (ed.) Sedimentary environments, processes, facies and stratigraphy. 2 ed. Oxford. Blackwell Science. p. $37-82$.

DEER, W.A.; HOWIE, R.A.; ZUSSMAN, J. 1992. An introduction to the rock-forming minerals. Essex, Longman Scietific \& Technical. 696p.

DE ROS, L.F.; MORAD, S.; PAIM, P.S.G. 1994. The role of detrital composition and climate on the diagenetic evolution of continental molasses: evidence from the CambroOrdovician Guaritas sequence, southern Brazil. Sedimentary Geology, 92(3-4): 197228. 
DICKINSON, W.R. 1985. Interpreting provenance relations from detrital modes of sandstones. In: Zuffa, G.G. (Ed.), Provenance of Arenites. Reidel, Dordrecht, pp 333361

FACCINI, U.F.; PAIM, P.S.G.; FRAGOSO-CESAR, A.R.S. 1987. Análise faciológica das molassas brasilianas na região das Minas do Camaquã, Eo-paleozóico do RS. In: SBG, Simpósio Sul-Brasileiro de Geologia, 3., Curitiba, Atas, 1:75-91.

FOLK, R.L. 1968. Petrology of sedimentary rocks. Austin, Hemphill Publ. Co. 170p.

FRAGOSO-CESAR, A.R.S. 1980. O Cráton Rio de La Plata e o Cinturão Dom Feliciano no Escudo Uruguaio-Sul-Riograndense. In: SBG, Congresso Brasileiro de Geologia, 31, Camboriú, Anais, 5: 2879 - 2892.

FRAGOSO-CESAR, A.R.S. 1991. Tectônica de Placas no Ciclo Brasiliano: as Orogenias dos Cinturões Dom Feliciano e Ribeira no Rio Grande do Sul. Tese de Doutoramento, IGc-USP, São Paulo, SP, 366p.

FRAGOSO-CESAR, A.R.S.; LAVINA, E.L.; PAIM, P.S.G.; FACCINI, U.F. 1984. A Antefossa Molássica do Cinturão Dom Feliciano no Escudo do Rio Grande do Sul. In: Congresso Brasileiro de Geologia, 33, Rio de Janeiro, Anais... Rio de Janeiro, SBG. v.7, p.3272-3283.

FRAGOSO-CESAR, A.R.S.; FACCINI, U.F.; PAIM, P.S.G.; LAVINA, E.L.; ALTAMIRANO, J.A.F. 1985. Revisão na estratigrafia das molassas do Ciclo Brasiliano no Rio Grande do Sul. In: II Simpósio Sul-Brasileiro de Geologia, Florianópolis, Anais... Florianópolis, SBG, p. 477-491.

FRAGOSO CÉSAR A.R.S., FIGUEIREDO M.C.H., SOLIANI JR. E., FACCINI U.F. 1986. O Batólito Pelotas (Proterozóico Superior/Eo-Paleozóico) no Escudo do Rio Grande do Sul. In: SBG, Congresso Brasileiro de Geologia, 34, Goiânia, Anais, 3:1322-1343.

FRAGOSO-CESAR, A.R.S.; SILVA FILHO, W.F.; FAMBRINI, G.L.; MACHADO, R.; RICCOMINI, C.; ALMEIDA, R.P.; PELOSI, A.P.M.R.; JANIKIAN, L. 1999. Significado tectônico do magmatismo Rodeio Velho no rift Guaritas (Eopaleozóico do Rio Grande do Sul, Brasil). In: Simpósio sobre vulcanismo e ambientes associados, Boletim de resumos, p.16.

GALEHOUSE, J.S., 1971. Point-counting. In: Carver, R.E. (Ed.), Procedures in Sedimentary Petrology. Wiley- Interscience, New York, pp. 385-407.

GUEDES, C.C.F.; GIANNINI, P.C.F.; NASCIMENTO JR., D.R.; SAWAKUCHI, A.O.; TANAKA, A.P.B.; ROSSI, M.G. 2011. Controls on heavy-mineral and grain-size in a 
Holocene regressive barrier (Ilha Comprida, Southeastern Brazil). Journal of South American Earth Sciences, 31: 110-123.

HUBERT, J.F. 1962. A zircon-tourmaline-rutile maturity index and the independence of the composition of heavy mineral assemblages with the gross composition and texture of sandstones. J. Sediment. Petrol., 32(3):440-450.

HUNTER, R.E. 1977. Basic types of stratification in small eolian dunes. Sedimentology 24: $361-387$.

HUNTER, R.E. 1981. Stratification styles in eolian sandstones: some Pennsylvanian to Jurassic exemples from western interior U.S.A. In: F.G. Ethridge \& R.M. Flores (eds), Recent and Ancient Nonmarine Depositional Environments: Models for Exploration. SEMP Special Publication 31: 315-329.

KLEIN, C. 2002 Mineral Science. John Wiley \& Sons, New York. 646pp.

KOCUREK, G. 1996. Desert aeolian systems. In: H. G. Reading (ed.) Sedimentary environments, processes, facies and stratigraphy. 2 ed. Oxford. Blackwell Science. p. 125-153.

LANGFORD, R.P. 1989. Fluvial-aeolian interactions: Part 1, Modern Systems. Sedimentology 36(6):1023-1035.

LANGFORD, R.P. \& CHAN, M.A. 1989. Fluvial-aeolian interactions: Part 2, Ancient Systems. Sedimentology 36(6):1037-1051.

LAVINA, E.L.; FACCINI, U.F.; PAIM, P.S.G.; FRAGOSO-CESAR, A.R.S. 1985. Ambientes de sedimentação da Bacia do Camaquã, Eo-paleozóico do Rio Grande do Sul. Acta Geologica Leopoldensia, 21(9): 185-227.

MANGE, M.A. \& MAURER, H.F.W. 1992. Heavy Minerals in Colours. Chapman \& Hall, London.

MARCONATO, A.; ALMEIDA, R.P.; SANTOS, M.G.M.; NÓBREGA, J.E.S.; SOUZA, R.B. 2009. Alluvial-eolian interaction in a Cambrian rift margin: the Pedra das Torrinhas and Pedra Pintada formations (Guaritas Group, RS). In: Anais da Academia Brasileira de Ciências, 81(4): 819- 836

MATTOS, I.C.; PHILLIPP, R.P.; MEXIAS, A.S.; GOMES, M.E.B. 2004 Metamorfismo de contato no Complexo Bossoroca, porção SW do Complexo Granítico São Sepé, RS. Revista Brasileira de Geociências, 34(1):1-10

McKEEVER, S.W.S. 1985. Thermoluminescence of Solids. , Cambridge University Press, Cambridge. 
MIALL, A.D. 1996. The Geology of Fluvial Deposits: Sedimentary Facies, Basin Analysis and Petroleum Geology. 852p. Springer. Berlin.

MIALL, A.D. 2000. Principles of sedimentary basin analysis. 3nd ed., New York, Springer-Verlag, $616 \mathrm{p}$.

MORTON, A.C. 1985. Heavy minerals in provenance studies. In: Zuffa, G.G. (Ed.), Provenance of Arenites. Reidel, Dordrecht, pp. 249-277.

MORTON, A.C. \& HALLSWORTH, C.R. 1994. Identifying provenance-specific features of detrital heavy mineral assemblages in sandstones. Sedimentary Geology, 90: 241256.

MORTON, A.C. \& HALLSWORTH, C.R. 1999. Processes controlling the composition of heavy mineral assemblages in sandstones. Sedimentary Geology, 124: 3-29.

NAIME, R.H. \& NARDI, L.V.S. 1991 O granito da Ramada, porção oeste do escudo sulrio-grandense: geologia, petrologia e geoquímica. Revista Brasileira de Geociências 21(3): 266-274.

NARDI, L.V.S. \& BITENCOURT, M.F. 1989. Geologia, Petrologia e Geoquímica do Complexo Granítico de Caçapava do Sul, RS. Revista Brasileira de Geociências, 19(2): 153-169.

NARDI, L.V.S. \& LIMA, E.F. 2000. Hybridisation of mafic microgranular enclaves in the Lavras Granite Complex, southern Brazil. Journal of South American Earth Sciences, 13: $67-78$.

NASCIMENTO, M.S.; GÓES, A.M.; MACAMBIRA, M.B.; BROD, J.A. 2007. Provenance of Albian deposits in the São Luís-Grajaú Basin determinated from palaeocurrent patterns, $\mathrm{Pb}-\mathrm{Pb}$ zircon dating and mineral chemistry of tourmaline, northern Brazil. Sedimentary Geology, 201: 21-42.

NÓBREGA, J.E.S.; SAWAKUCHI, A.O.; ALMEIDA, R.P. 2008. Minerais pesados das porções média e superior do Grupo Guaritas (Eocambriano, RS): considerações sobre a proveniência sedimentar. Revista Brasileira de Geociências, 38(3): 554-565.

PAIM, P.S.G. 1994. Depositional Systems and Paleogeographical Evolution of the Camaquã and Santa Bárbara Basins, Brazil. Phil. Doctor Thesis, Oxford. v.I, 277 p.

PAIM, P.S.G. 1996. O sistema desértico úmido Pedra Pintada (cambro-ordoviciano do RS). In: Congresso Brasileiro de Geologia, 39. Salvador, 1996. Anais... Salvador, SBG. Boletim de Resumos Expandidos 2: 207-209.

PAIM, P.S.G. \& SCHERER, C.M.S. 2003. Arquitetura Estratigráfica de sucessões flúvioeólicas: o exemplo do Alogrupo Guaritas na região da Pedra Pintada, Rio Grande do 
Sul, Brasil. In: P.S.G. Paim, U.F. Faccini, R.G. Netto (eds). Geometria, arquitetura e heterogeneidades de corpos sedimentares - Estudos de casos. Unisinos. p. 38-58.

PAIM, P.S.G.; LOPES, R.C.; CHEMALE JR., F. 1995. Aloestratigrafia, sistemas deposicionais e evolução paleogeográfica da Bacia do Camaquã -Vendiano Superior/ Ordoviciano Inferior do RS. In: VI Simpósio Sul-Brasileiro de Geologia / I Encontro Geologia do Cone Sul, Porto Alegre, SBG/Núcleo RS. Boletim de Resumos Expandidos, p. $39-50$.

PAIM, P.S.G.; CHEMALE JR, F.; LOPES, R.C. 2000. A Bacia Camaquã. In: M. Holtz \& L.F. De Ross (eds) Geologia do Rio Grande do Sul. Universidade Federal do Rio Grande do Sul. p.232-274.

PARFERNOFF, A.; POMEROL, C.; TOURENQ, J. 1970. Les Minéraux en Grains: Methods d'etude et determination. Paris, Masson. 571p.

PETTIJOHN, F.J. 1941. Persistence of heavy minerals and geologic age. Jour. Geology, 46: $610-625$.

PETTIJOHN, F.J. 1975. Provenance. In: Sedimentary Rocks. 3ed. New York, Harper \& Row, Publ. p.483-505.

PHILIPP, R.P. \& MACHADO, R. 2001. Suites graníticas do Batólito de Pelotas no Rio Grande do Sul: petrografia, tectônica e aspectos petrogenéticos. Revista Brasileira de Geociências, 31(3): 257-266.

PIESTCH, T.J., OLlEY, J.M., NANSON, G.C., 2008. Fluvial transport as a natural luminescence sensitiser of quartz. Quaternary Geochronology 3, 365-376.

PREUSSER, F.; CHITHAMBO, M.L.; GÖTTE, T.; MARTINI, M.; RAMSEYER, K.; SENDEZERA, E.J.; SUSINO, G.J.; WINTLE, A.G. 2009. Quartz as a natural luminescence dosimeter. Earth-Science Reviews 97(1-4): 184-214.

RIBEIRO, M.; BOCCHI, P. R.; FIGUEIREDO FILHO, P. M.; TESSARI, R. I. 1966. Geologia da quadrícula de Caçapava do Sul, Rio Grande do Sul. Rio de Janeiro, DNPM/DFPM, 232 p. (Boletim 127).

RINK, W.J. 2003. Thermoluminescence of quartz and feldspar sand grains as a tracer of nearshore environmental processes in the southeastern Mediterranean Sea. Journal of Coastal Research, 19(3):723-730.

RINK, W.J.; RENDELL, H.; MARSEGLIA, E.A.; LUFF, B.J.; TOWNSEND, P.D. 1993. Thermoluminescence spectra of igneous quartz and hydrothermal vein quartz. Phys. Chem. Minerals, 20:353-361

ROBERTSON, J. F. 1966. Revision of Stratigraphy and nomenclature of rock units in 
Caçapava-Lavras Region. Notas e Estudos, IG-UFRGS, Porto Alegre, 1(2): 41-54.

SANTOS, M.G.M. 2010. Tectônica e Sedimentação na Bacia do Camaquã Central (RS):

Exemplos do Grupo Guaritas e do Grupo Santa Bárbara. Dissertação de Mestrado.

Instituto de Geociências - Universidade de São Paulo, SP. 180pp

SAWAKUCHI, A.O.; BLAIR, M.W.; DeWITT, R.; FALEIROS, F.M.; HYPPOLITO,

T.N.; GUEDES, C.C.F. 2010. Thermal history versus sedimentary history: OSL sensivity of quartz grains extracted from rocks and sediments. Quaternary Geochronology (in press).

STANISTREET, I.G. \& STOLLHOFEN, H. 2002. Hoanib River flood deposits of Namib Desert interdunes as analogues for thin permeability barrier mudstone layers inaeolianite reservoirs. Sedimentology, 49: 719- 736.

VAN ANDEL, TJ. H. 1950. Provenance, transport and deposition of Rhine sediments. H. Veeman en Zonen, Wageningen.

WELTJE, G.J. \& von EYNATTEN, H. 2004. Quantitative provenance analysis of sediments: review and outlook. Sedimentary Geology 171: 1-11. 